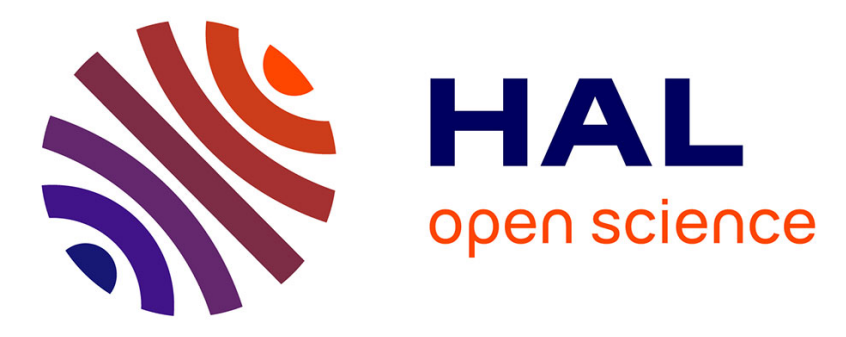

\title{
Quartz vein geochemistry records deformation processes in convergent zones
}

Hugues Raimbourg, Kristijan Rajič, Benjamin Moris-muttoni, Vincent Famin, Giulia Palazzin, Donald Fisher, Kristin Morell, Saskia Erdmann, Ida Di Carlo, Clément Montmartin

\section{- To cite this version:}

Hugues Raimbourg, Kristijan Rajič, Benjamin Moris-muttoni, Vincent Famin, Giulia Palazzin, et al.. Quartz vein geochemistry records deformation processes in convergent zones. Geochemistry, Geophysics, Geosystems, 2021, 22 (4), pp.e2020GC009201. 10.1029/2020GC009201 . insu-03162829

\section{HAL Id: insu-03162829 \\ https://hal-insu.archives-ouvertes.fr/insu-03162829}

Submitted on 8 Mar 2021

HAL is a multi-disciplinary open access archive for the deposit and dissemination of scientific research documents, whether they are published or not. The documents may come from teaching and research institutions in France or abroad, or from public or private research centers.
L'archive ouverte pluridisciplinaire HAL, est destinée au dépôt et à la diffusion de documents scientifiques de niveau recherche, publiés ou non, émanant des établissements d'enseignement et de recherche français ou étrangers, des laboratoires publics ou privés. 


\section{Quartz vein geochemistry records deformation processes in convergent zones}

Hugues Raimbourg ${ }^{\mathrm{a}}$, Kristijan Rajiča ${ }^{\mathrm{a}}$, Benjamin Moris-Muttoni ${ }^{\mathrm{a}}$, Vincent Famin ${ }^{\mathrm{b}}$, Giulia Palazzina ${ }^{\mathrm{a}}$, Donald Fisher ${ }^{c}$, Kristin Morell ${ }^{d}$, Saskia Erdmann ${ }^{a}$, Ida Di Carlo ${ }^{a}$, Clément Montmartin ${ }^{a}$

(a) Univ. Orléans, CNRS, BRGM, ISTO, UMR 7327, F-45071, Orléans, France

(b) Laboratoire Géosciences Réunion, Université de La Réunion, IPGP, Sorbonne Paris Cité, UMR 7154 CNRS, Saint-Denis, La Réunion, France

(c) Department of Geosciences, Penn State University, University Park, PA 16802, USA

(d) Department of Earth Science, University of California, Santa Barbara, 1006 Webb Hall, Santa Barbara, CA 93106, USA

\section{Key points}

1) Variations in $\mathrm{Al}$ and Li concentration in hydrothermal quartz span more than 2 orders of magnitude and are up to 3000 and $400 \mathrm{ppm}$

2) Growth rims with large Al and Li concentrations are present only at seismogenic depth and might reflect large fluid pressure drops

3) Crack-seal microstructures formed at the down-dip limit of the seismogenic zone might be associated with smaller fluid pressure variations

\section{Abstract}

In several examples of subduction zones, we compared pairs of quartz veins formed either at the lower temperatures of the seismogenic zone $\left(260^{\circ} \mathrm{C}\right.$ or below), or at the higher temperatures of its downdip limit $\left(\sim 330^{\circ} \mathrm{C}\right)$. All the veins analyzed here are mode I cracks that formed contemporaneously with the host-rock main stage of deformation at peak burial conditions. Lower temperature veins show examples of quartz crystals with euhedral shapes and growth rims, while higher temperature veins contain crack-seal microstructures. In the lower temperature realm, quartz growth rims have alternatingly either: 1 ) high cathodoluminescence (CL), CL-blue color and high concentration in trace elements and fluid inclusions, or 2) low luminescence, CL-brown color and low concentration in trace elements and fluid inclusions. In contrast, the quartz from higher temperature samples is smogeneously low luminescent and CL-brown, except for very restricted domains of the crack-seal microstructures where patches of $\mathrm{CL}$-blue quartz are present. The highly luminescent quartz contains high concentrations of aluminum and lithium, up to 3000 and $400 \mathrm{ppm}$, respectively. Variations in Al and $\mathrm{Li}$ correlate well, so that Li appears as the main charge-compensating cation for Al. We propose that the incorporation of $\mathrm{Al}$ and Li reflects the amplitude of the fluid pressure variations, which control crystal growth rates. Quartz geochemistry might therefore unravel the contrast between the seismogenic zone, where large fluid pressure variations are present, and its downdip limit, where fluid pressure variations are much more limited in amplitude.

\section{Plain language summary}

We have examined several examples of veins that formed at large depths in collision and subduction zones. These veins formed as a result of the opening of a crack-shaped cavity and were filled by the precipitation of quartz from dissolved silica. These veins thus have characteristics that reflect the water that was present in the pores and cracks of the rock at depth. The samples we have analyzed come from either the seismogenic zone (for temperatures of the order of $\sim 260^{\circ} \mathrm{C}$ or lower), i.e. the depth This article has been accepted for publication and undergone full peer review but has not been through the copyediting, typesetting, pagination and proofreading process, which may lead to differences between this version and the Version of Record. Please cite this article as doi: 10.1029/2020GC009201.

This article is protected by copyright. All rights reserved. 
domain where large earthquakes are generated, or its downdip limit (for temperatures of the order of $\sim 330^{\circ} \mathrm{C}$ ), i.e. the depth domain below which deformation is principally non seismic. The chemistry of quartz varies strongly between these two depth domains. At temperatures of the order of $\sim 260^{\circ} \mathrm{C}$, the quartz contains either a large concentration in impurities, or is relatively pure. At higher temperatures, the quartz is essentially pure. We interpret the domains of quartz rich in impurities as having formed as a result of earthquakes, by rapid growth in disequilibrium conditions, when the pressure of the fluid dropped strongly and the fluid became suddenly highly oversaturated in dissolved silica, which then precipitated.

\section{Introduction}

Even if present in small quantities, the fluid in the pores of a rocks exerts a large control on its deformation. An example of such an effect is illustrated by the anticorrelation between coseismic coupling and fluid pressure along the Chile subduction zone (Moreno et al., 2014). Around the downdip limit of the seismogenic zone, episodic tremor and slip (ETS) is shown to be correlated with domains of high fluid pressure (Audet and Kim, 2016; Audet and Schwartz, 2013; Gomberg and Cascadia 2007 and Beyond Working Group, 2010).

Conversely, the effect of deformation of the solid matrix on pore fluid is attested at the surface by variations in water levels in wells and flow rates in springs in the vicinity of earthquake rupture zones (Elkhoury et al., 2006; Jonsson et al., 2003; Muir-Wood and King, 1993). Nonetheless, below a few kilometers of depth (i.e., in the depth range where earthquakes nucleate or where slow slip occurs), there are few direct observations of how fluid pressure varies in conjunction with the fluid flow response to the deformation of the solid matrix. Although indirect, the most comprehensive dataset on deep, synkinematic fluids is derived from veins that can be shown to form contemporaneously with the deformation of the surrounding rock (Fagereng et al., 2011; Palazzin et al., 2016; Ramsay, 1980). Some veins trap, a record of the fluid that was present during their growth, either in the vein-forming crystals or in fluid inclusions.

A significant constraint on the fluid pressure conditions at depth can be retrieved from veins through microthermometric studies of fluid inclusions. In convergent settings, fluid pressure changes recorded by concomitant trapping of $\mathrm{H}_{2} \mathrm{O}$-rich and $\mathrm{CO}_{2}$-rich fluid inclusions with very contrasting $\mathrm{P}-\mathrm{V}-\mathrm{T}$ properties have been observed in gold-bearing quartz veins and interpreted as a record of fluid pressure variations of the order of $\sim 150$ to $200 \mathrm{MPa}$, at temperature conditions of $\sim 350^{\circ} \mathrm{C}$ (Robert et al., 1995; Wilkinson and Johnston, 1996). In subduction zone settings, fluid pressure variations are also suggested by a large range of isochores of $\mathrm{CH}_{4}$-rich and $\mathrm{H}_{2} \mathrm{O}$-rich fluid inclusions (Mullis, 1979, 1988; Vrojlik, 1987). Assuming growth at a constant temperature $\left(220-230^{\circ} \mathrm{C}\right.$ and $260-290^{\circ} \mathrm{C}$ for Mullis (1988) and Vrojlik (1987), respectively), the difference in the properties of the fluid inclusions suggests fluid pressure variations of the order of $\sim 150 \mathrm{MPa}$. These estimates should be considered as order of magnitude, as many reequilibration processes, either by diffusion or by cracking, might affect the record of the fluid inclusions after entrapment (Hall and Sterner, 1993; Sterner and Bodnar, 1989; Sterner et al., 1995; Vityk and Bodnar, 1995; Vityk et al., 2000; Vityk et al., 1994).

Fluid pressure conditions at depth can also be characterized based on vein-forming minerals. In goldbearing quartz veins, the co-precipitation of gold and quartz might be explained by an extreme reduction in fluid pressure that leads to flash vaporization of the fluid (Weatherley and Wenley, 2013). Furthermore, crack-seal microstructures have been interpreted as reflecting cyclical processes of deformation and fluid pressure variations (Cox et al., 1986; Ramsay, 1980). Even if other microstructures attest to events of microcracking followed by sealing (Fisher et al., 2019a, b), we restrict here the term crack-seal microstructure to the typical microstructure of antitaxial veins with

This article is protected by copyright. All rights reserved. 
solid inclusion bands or trails such as described by Ramsay (1980). Such crack-seal microstructures have been described in subduction settings in the Shimanto Belt, Japan (Ujiie et al., 2018) and on Kodiak Island in Alaska, USA (Fisher and Brantley, 1992, 2014; Fisher et al., 1995), and have been tentatively interpreted as the expression of ETS at the base of the seismogenic zone (Fisher and Brantley, 2014). Nonetheless, as for fluid inclusions, the interpretation of crack-seal microstructures as reflecting discontinuous pulses of fluid and quartz growth is controversial, as alternative models of continuous growth can account for the formation of bands of fluid inclusions (see the review by Hilgers and Urai (2005)).

The idea of large and episodic fluid pressure changes is also supported by conceptual models of combined fluid flow and deformation, such as the fault-valve model; earthquakes result in a large and sudden increase in permeability, which can lead to large fluid transfer across a seal between fluid compartments (Sibson, 1994). Nonetheless, such a model, if valid for the upper part of the crust, might eventually break down at depths greater than the brittle-viscous transition. Indeed, the hydrological system in the viscous, lower part of the crust is fundamentally different from the seismogenic, upper region of the crust (Ague, 2015; Cox, 2001; Walther and Orville, 1982). The transitional domain is precisely the one where ETS is generated, and the hydrology of this transitional zone is enigmatic. Based on seismological arguments, Saffer and Tobin (2011) proposed an evolution from a moderately overpressured seismogenic zone to an extremely overpressured domain at larger depths. This transitional zone is also complex in terms of rheology, as this is the domain where brittle and viscous processes might coexist (Handy and Brun, 2004).

The objective of the present contribution is to describe the evolution with depth and temperature of the fluid pressure across the brittle-viscous transition in subduction zones. To do so, we used the geochemistry of synkinematic quartz veins chosen at different temperatures spanning this transition as a tool to infer the fluid properties during vein growth. For all the samples, which come from several worldwide examples of subduction zones, we have applied cathodoluminescence, LA-ICP-MS, and EPMA analyses on the veins and Raman spectroscopy on the carbonaceous matter (RSCM) sampled from the host rock. The contrast in geochemical features across the temperature range studied is used to unravel the very large variations in fluid pressure and temperature conditions, between the seismogenic zone and the zone of ETS below.

\section{Geological settings and choice of samples}

We collected veins from two accretionary prisms: the Kodiak archipelago in Alaska, USA, and the Shimanto Belt on the island of Kyushu, Japan (Figure 1). The sample GPS locations are given in Table 1.

The Kodiak Accretionary Complex consists of several juxtaposed belts, with ages that increase away from the modern trench. The Kodiak Formation forms a large proportion of the complex and is composed of folded and faulted turbidites of Late Cretaceous age (Moore, 1969a, b; Sample and Moore, 1987). It is subdivided into three belts (Landward, Central and Seaward Belts), on the basis of regional variations in bedding and cleavage attitudes. The strongly deformed Central Belt is characterized by numerous southeast-verging thrust faults (Fisher, 1985; Sample and Fisher, 1986; Sample and Moore, 1987) and contains many syn-kinematic quartz veins (Fisher and Brantley, 1992, 2014; Fisher and Byrne, 1990). On the northwestern part of the islands of Kodiak and Afognak, the coherent rocks of the Kodiak Formation are juxtaposed along the Uganik Thrust (Rowe et al., 2009). The Uganik Thrust places the Kodiak Formation in fault contact with the Uyak Complex, a mélange composed of lenses of basalt and cherts in a sedimentary matrix of mid-Permian to mid-Early Cretaceous biostratigraphic age, which was accreted prior to the Kodiak Formation during the Late Cretaceous (Connelly, 1978). Similar to the Kodiak Belt, the Uyak Mélange was strongly deformed

This article is protected by copyright. All rights reserved. 
during top-to-the-southeast underthrusting (Moore and Wheeler, 1978), and contains abundant veins formed contemporaneously with deformation (Vrojlik, 1987). The two samples studied here come from the Uyak Complex and the Kodiak Central Belt along a transect in the northeastern side of Afognak Island (Brantley et al., 1997; Fisher and Byrne, 1987). The Kodiak Central Belt contains the most deformed rocks of the Kodiak Formation that are exposed in a structural culmination (Fisher and Byrne, 1992). The vein samples from the Kodiak Central Belt are similar to the ones described in Fisher and Brantley $(1992,2014)$, which contain crack-seal microstructures.

The Shimanto Belt is the on-land, Cretaceous to Miocene equivalent of the modern Nankai Trough accretionary prism (Taira, 1981; Taira et al., 1988; Taira et al., 1980; Tanaka and Nozawa, 1977). On Kyushu Island, the Shimanto Belt near the city of Nobeoka is composed of a stack of northwest-dipping thrust sheets. The Nobeoka Tectonic Line (NTL) is a major fault zone separating the Cretaceous from the Cenozoic part of the belt (Murata, 1996, 1997, 1999; Raimbourg et al., 2014a). Structurally above the NTL, the Morotsuka Group comprises strongly sheared horizons including deep-sea sediments and basalt lenses (Mackenzie et al., 1989; Sakai and Kanmera, 1981; Ujiie et al., 2018). A strong metamorphic foliation is developed in the basal part of the Morotsuka Group, along with a N-S or NNW-SSE stretching lineation (Fabbri et al., 1987; Raimbourg et al., 2014a; Ujiie et al., 2018). The Hyuga Group forms the footwall of the NTL. Its upper horizon, the Hyuga Tectonic Mélange, is formed of basalt and sandstone lenses in a pelitic matrix. This melange is deformed by a dense network of topto-the-SE shear bands that are interpreted to have formed during subduction (Raimbourg et al., 2014a). Below the Hyuga Tectonic Mélange, a coherent formation composed of turbidites (Coherent Hyuga), is less deformed, except for a few crosscutting fault zones with the same kinematics as the overlying mélange. The density of these faults increases towards its upper boundary, a thrust fault that was possibly activated during a collisional event in the Early Miocene (Murata, 1991, 1996, 1998; Raimbourg et al., 2014a). The temperature structure of the Shimanto Belt on Kyushu was constrained by earlier studies using either vitrinite reflectance (Kondo et al., 2005), RSCM (Raimbourg et al., 2014a; Raimbourg et al., 2017a), or illite crystallinity (Hara and Kimura, 2008; Mukoyoshi et al., 2009). All these studies show an increase in temperature towards the inner wedge, with gaps corresponding to the main faults. In the zone of study, the temperature in the Coherent Hyuga, Hyuga Tectonic Mélange and Morotsuka Group are $\sim 200^{\circ} \mathrm{C}, \sim 250^{\circ} \mathrm{C}$ and $\sim 330-350^{\circ} \mathrm{C}$ respectively (Raimbourg et al., 2018; Raimbourg et al., 2017a). The samples studied here come from the Morotsuka Group, the Hyuga Tectonic Mélange and the Coherent Hyuga, in order to analyze a relatively large temperature range, from the seismogenic zone to its downdip limit. The veins from the Morotsuka Group are of the same type as those described in Ujiie et al. (2018) and Nishiyama et al. (2020), which contain crack-seal microstructures.

\section{Methods}

\section{Structural analysis of veins}

For each area investigated, we measured vein geometry, along with the orientation and kinematics of coexisting shear zones or faults. We carried out the structural analysis over entire cross-sections of the thrust belts, to make sure that the veins selected are representative of a regional pattern and can be interpreted within the context of a tectonic process-based framework.

\section{Temperature of veining from Raman Spectroscopy of Carbonaceous Material}

The vein samples studied here are all hosted in mudstone-rich rocks, which contain abundant, very fine (<micron-scale) carbonaceous material appropriate for RSCM (Beyssac et al., 2002; Lahfid et al., 2010). Raman spectra were obtained using a Renishaw InVIA Reflex microspectrometer (ISTO-BRGM;

This article is protected by copyright. All rights reserved. 
Orléans). A laser ( $514 \mathrm{~nm}$ ) was focused on the sample by a DM2500 Leica microscope equipped with an $\times 100$ objective. Instrument control and Raman measurements were performed with the software package Renishaw Wire 4.0. Acquisition time was $3 \mathrm{~s}$ and spectra were accumulated 30 times. To avoid defects on the carbonaceous material related to thin-section preparation, analyses were all performed below the surface of the section by focusing the laser beam beneath a transparent crystal (i.e. dominantly quartz and occasionally calcite or albite). The laser beam power at the surface of the sample was set to $\sim 0.5 \mathrm{~mW}$.

Focusing on the range mostly below $350^{\circ} \mathrm{C}$ of the crystalline evolution of carbonaceous matter, we used the procedure by Lahfid et al. (2010), which is valid up to $320^{\circ} \mathrm{C}$, to decompose the spectra. We used the software PeakFit 4.12 to: (i) substract the baseline (by using linear baseline defined by points in the $900-1000 \mathrm{~cm}^{-1}$ and $1900-2000 \mathrm{~cm}^{-1}$ ranges) and (ii) fit the resulting spectra by 5 Lorentzian functions. When converted into temperatures, some of our spectra yielded temperatures slightly above $320^{\circ} \mathrm{C}$, but for the sake of using a consistent approach, we used only the paleothermometer described in Lahfid et al. (2010).

Beyond the method used to derive paleotemperatures, a further difficulty arises in attributing the inferred temperature to the formation of the veins, as the veins might have precipitated before or after the peak recorded in the RSCM. We consider that paleotemperatures as representative of vein formation when the structural evidence allows one to ascribe the veining stage to the peak in burial and temperature. Additionally, where possible, the RSCM temperature estimates were compared with the minimum temperature of vein fluids determined from homogenization temperatures of fluid inclusions.

\section{Cathodoluminescence imaging}

Thick sections of veins were placed in a vacuum chamber at an Argon pressure of $\sim 60.10^{-3} \mathrm{mbar}$. They were irradiated by a cold cathode source electron gun provided by OPEA (France). Standard voltagecurrent beam conditions were maintained at $\sim 13-15 \mathrm{kV}$ and $90-110 \mu \mathrm{A}$, respectively. The angle between the gun axis and horizontal was $18^{\circ}$. The chamber was placed on a simplified optical mount designed to minimize light absorption on the beam pathway. The optical stage was equipped with a Retiga 2000R 1394a cooled camera (captor size 1 inch, resolution $1600 \times 1200$ pixels, square pixel size $7.4 \mu \mathrm{m}$ ). Given the low luminescence of quartz, acquisition time was fixed to ca. 10s. Whenever present, the strong luminescence of carbonate veins prevented the analysis of quartz.

\section{EPMA analysis of composition}

Aluminum concentration in quartz samples was analyzed by compositional mapping with electron probe micro analysis (EPMA). The maps were acquired on Cameca SX Five housed at ISTO-BRGM joint facilities in Orleans. The voltage was set at $15 \mathrm{kV}$ and the current at $200 \mathrm{nA}$ for all maps (Figure 10, Figure 12, Figure 13), but for one where it was set at $250 \mathrm{nA}$ (Figure 11). Step size and dwell time were set at $1 \mu \mathrm{m}$ and $150 \mathrm{~ms}$ for all maps, but for the map in Figure 11 where they were set at $2 \mu \mathrm{m}$ and 270 ms.

\section{LA-ICP-MS analysis}

We carried out our analyses on double-polished thick sections ( 150 to $200 \mu \mathrm{m}$ ) of vein material, which were, prior to ablation, removed from the glass slide by immersion for more than $24 \mathrm{~h}$ in acetone and then carefully cleaned with acetone for remains of glue. The margins of the thick sections were subsequently fixed to a new glass plate with cyanoacrylate glue. On these sections, we restricted our

This article is protected by copyright. All rights reserved. 
analyses to the domains of clear quartz, i.e. free or with a very low density of fluid inclusions. These domains are rare in the veins, which limits the amount of available material.

The LA-ICP-MS analyses were conducted at the CNRS, Institut de Sciences de la Terre d'Orléans (ISTO), using a RESOlution-SE $193 \mathrm{~nm}$ ArF excimer laser with a S155 ablation cell coupled to an Agilent 8900 $\mathrm{QQQ}$ mass spectrometer. The ablation chamber of the laser ablation system was flushed with $\mathrm{He}$ (350 $\mathrm{ml} / \mathrm{min})$ and $\operatorname{Ar}(15 \mathrm{l} / \mathrm{min})$, to which further $\operatorname{Ar}(\sim 0.9 \mathrm{l} / \mathrm{min})$ was added on the way to the ICP-MS. The ICP-MS was tuned on NIST612 to low production rates of ThO and doubly-charged ${ }^{42} \mathrm{Ca}$ of $<0.15 \%$ and $<0.30 \%$, respectively, and to a $\mathrm{U} / \mathrm{Th}$ ratio of $100 \pm 1 \%$.

For the quartz analyses, the laser was operated at a frequency of 10 or $5 \mathrm{~Hz}$, set to deliver a fluence of $8 \mathrm{~J} / \mathrm{cm}^{2}$ on the sample surface, using an analytical spot size $50 \mu \mathrm{m}$ in diameter. These conditions (especially the lower ablation frequency of $5 \mathrm{~Hz}$ ) were found to provide good ablation results. Background and ablation signals were acquired for 30 and $40 \mathrm{~s}$, respectively. For each spot, the concentrations of ${ }^{7} \mathrm{Li},{ }^{23} \mathrm{Na},{ }^{27} \mathrm{Al},{ }^{28} \mathrm{Si}$ and ${ }^{39} \mathrm{~K}$ were determined using dwell times of $50 \mathrm{~ms}$ for each isotope. Before and after each set of 10-12 sample analyses, 3 analyses of NIST610 and 2 analyses of NIST612 have been performed. NIST610 was used as an external standard for calibration of all acquired data. $\mathrm{SiO}_{2}$ was used as an internal standard following the assumption that each point contains close to 100 wt\%. NIST 612 was analyzed for quality control, which showed that accuracy and precision were $\leq 2-5 \%$.

For data reduction, we used the software GLITTER ${ }^{\text {TM }}$ (Van Achterbergh et al., 2001), where we have rigorously inspected and manually selected background and ablation signals, applying a linear fit to all standard data. Despite performing ablation at optimized conditions, initial ablation on quartz commonly caused catastrophic failure (spallation of larger quartz fragments), typically for the first $<5$ s. Such catastrophic ablation resulted in artificially heightened concentration peaks for $\mathrm{Na}, \mathrm{K}$ and possibly affecting other elements. In our data reduction, we excluded such concentration peaks, and accordingly excluded the first 5 to $10 \mathrm{~s}$ of ablation signal in the integration.

\section{Results}

\section{Vein structures/microstructures}

\section{1) Structures :}

To study comparable structures throughout the different field examples, we focused here on mode I cracks perpendicular to the macroscopic stretching direction. Typical mode I quartz vein structures are shown in Figure 2 and Figure 3 and summarized as a sketch in Figure 4, while the corresponding structural data are presented in Figure 5.

Deformation occurs by simple shear in the Coherent Hyuga and in the Hyuga Tectonic Mélange, with a dense network of shear zones with top-to-the-SE sense of shear (Figure 5). In the Morotsuka Group, the deformation seems mainly coaxial, with a foliation close to horizontal and quartz vein fibers orientated NNW-SSE. Evidence for a contribution of simple shear is nonetheless present in the Morotsuka Group, mostly in the form of en échelon sets of veins indicating top-to-the-S sense of shear (Figure 2B).

In the Kodiak accretionary prism, the Uyak Complex has a spatially variable pattern of deformation. Some outcrops have conjugate sets of shear bands symmetrical about the foliation, indicating NW-SE extension. Other outcrops show a dominant simple shear, with top-to-the-SE shear bands (Figure 5). In the Kodiak Central Belt, the area investigated shows also either top-to-the-NW or top-to-the-SE shear bands filled with quartz and associated with mode I veins. In addition, en-échelon veins are widespread over the area, and indicate a top-to-the-SE sense of shear (Figure 2D).

This article is protected by copyright. All rights reserved. 
In summary, the strain ellipsoid in all these examples is either simple shear or a combination of pure shear and simple shear (Figure 4). The contribution of pure shear is larger in the higher temperature examples in the Shimanto Belt and the Kodiak accretionary prism. In all the examples, the mode I veins considered are perpendicular, or at a high angle to the foliation, and perpendicular or at high-angle to the $X$ finite strain axis.

In homogeneous, clay-rich lithologies, Mode I veins cut across the metamorphic foliation at high angle, sometimes with an en-échelon geometry, and are also folded and shortened perpendicular to the foliation (Figure 2). In more heterogeneous lithologies, Mode I veins are principally developed in the boudinaged portions of rocks more rigid than the shale matrix, e.g. sandstone layers or lenses embedded in shales, at high angle to the foliation (Figure 3). In many instances, Mode I veins are mode abundant in the vicinity of quartz-filled shear bands (Figure $2 \mathrm{C}$ and Figure $3 \mathrm{~A}$ and $\mathrm{B}$ ). The shear bands have a low to moderate angle to the foliation. In general, they have a fibrous structure, with fibers parallel to the stretching lineation present on the foliation plane. In some instances, the shear bands are the result of the evolution of an en-échelon set of mode I veins (Figure 2D).

\section{2) Microstructures :}

For the present sudy, we subdivided the microstructures of quartz into two categories: growth rims and crack-seals. Growth rim microstructures (Figure 6) were observed in the Coherent Hyuga, in the Hyuga Tectonic Mélange in Japan and in the Uyak Complex in Alaska (Figure 3). The quartz crystals forming the veins occasionally exhibit crystal facets pointing towards the inner axis of the crack.

Under the optical microscope, the growth rims are in most instances underlined by sharp contrasts in the density of fluid inclusions (Figure 6 left). In CL, the growth rims appear as alternations of CL-blue, high luminescence and CL-brown, low-luminescence domains within the crystal (Figure 6 right). In many instances, the $\mathrm{CL}$-blue rims correlate with domains of quartz with a high density of fluid inclusions (Figure 6A, C, D, Figure 7), but other examples show no correlation (Figure 6B). The CL-blue luminescence is evanescent, i.e. it disappears after a few tens of seconds of beam exposure and the $\mathrm{CL}$-color then changes to brown.

Crack-seal microstructures were observed in quartz veins from the Kodiak Central Belt (following Fisher and Byrne (1990)) and from the Morotsuka Group in the Shimanto Belt (following Ujiie et al. (2018)) (Figure 8). The crack-seal microstructures that we analyzed are located in mode I veins at high-angle to the foliation S1 (Figure 2).

The crack-seal microstructures consist of bands of solid inclusions between bands of quartz (Figure 8 left). The spacing of these solid inclusion bands is often $\sim 10-20 \mu \mathrm{m}$ but relatively irregular. The crackseal microstructures have a limited lateral extent and most often are restricted to the interior of a single, elongate quartz grain (Figure $8 \mathrm{~B}, \mathrm{C}$ ). In most instances, the quartz grains hosting the crack-seals are elongate perpendicular to the crack-seal bands (Figure $8 \mathrm{C}$ ).

The quartz crystal surrounding the crack-seal has a homogeneous, CL-brown (or purple) color of luminescence, and has a low intensity of luminescence. The quartz within the crack-seal microstructure has the same luminescence (Figure $8 \mathrm{C}$ ), except for restricted portions showing a much higher luminescence with CL-blue colors (Figure $8 \mathrm{~A}$ and $\mathrm{B}$, see also Figure 12 and Figure 13). The solid inclusions within the quartz are non-luminescent.

\section{Temperature of deformation and veining}

The paleotemperature data derived from RSCM and associated with the veins are detailed in Table 1, while typical spectra are shown in Figure 9. In the Kodiak Accretionary Complex, additional

This article is protected by copyright. All rights reserved. 
temperature data are provided for the NE transect along NE Afognak Island, near Big waterfall Bay (Table 2).

There is a significant temperature difference, illustrated in the shape of Raman spectra, between the lower and the higher temperature units of the Shimanto Belt and the Kodiak Accretionary Complex. In these two examples, the crack-seal structures with homogeneous brown $\mathrm{CL}$ are found in the higher temperature units $\left(\mathrm{T}^{\sim} 300-350^{\circ} \mathrm{C}\right)$, while the growth rim structures, with contrasts in luminescence, are found in the lower temperature units $\left(T^{\sim} 200-260^{\circ} \mathrm{C}\right)$.

\section{EPMA analysis of quartz composition}

Lower-temperature microstructures (growth rims):

Quartz vein samples precipitated at temperature below or or on the order of $250^{\circ} \mathrm{C}$ show growth rims, evidenced by sharp variations in fluid inclusion density and in luminescence (Figure 6). EPMA maps of these growth rims show that the CL-blue, high-luminescence correlates with high aluminum content, so that the growth rims visible in $\mathrm{CL}$ are also apparent in $\mathrm{Al}$ concentration maps (Figure 10 and Figure 11).

Two growth rim examples from the Shimanto Belt (Coherent Hyuga) and the Kodiak accretionary prism (Uyak Complex) that showed the presence of CL zoning were analyzed by EPMA (see locations in Table 1). These samples show zonings of $\mathrm{Al}$, while all the other elements, such as $\mathrm{K}$ or $\mathrm{Na}$, do not show any zoning. As a general rule, there is a much larger contrast in Al content in Shimanto Belt samples (Figure 10) than in Kodiak samples (Figure 11). Despite these differences, in both cases, Al zonings correlate with cathodoluminescence zonings, so that bright blue $\mathrm{CL}$ zones correspond to high Al concentration zones and dark brown CL zones to low Al concentration zones (Figure 10 and Figure 11).

The Al-rich rims have a relatively complex structure, with large heterogeneties in Al content. A network of low-luminescence channels isolate regions with a large Al content (Figure 10). In addition, spots of very high $\mathrm{Al}$ and $\mathrm{K}$ contents are present in the network of low-luminescence channels. These $\mathrm{K}$ - and $\mathrm{Al}-$ rich spots correlate with individual fluid inclusions and might correspond to small clay particles wrapping the cavities.

Higher-temperature microstructures (crack-seal):

Two crack-seal examples were analyzed by EPMA from the Shimanto Belt and the Kodiak accretionary prism, both of which show the presence of patches of high-luminescence, CL-blue quartz, in addition to the dominant, low-luminescence, CL-brown quartz. Both samples display variations in $\mathrm{Al}$ concentration that correspond to crack-seal microstructures, whereas other elements like $\mathrm{K}$ do not correlate to these microstructures (Figure 12 and Figure 13).

In the two examples, the CL-blue quartz within the crack-seal microstructures has a higher Al content than the surrounding, $\mathrm{CL}$-brown quartz. The contrast in luminescence/Al concentration occurs within a single quartz grain (Figure 12).

In one example, the quartz between the solid inclusion bands has a homogeneous Al concentration (Figure 12). In another example, the luminescence and Al content within the quartz domain of the crack-seal microstructure have a more complex distribution (Figure 13). The zones of blue luminescence and high Al content constitute local patches but not all of the crack-seal quartz. At the higher resolution given by EPMA, contrasts in quartz Al content, in the form of series of bands of variable content, occur within a single quartz band bordered by two successive inclusion bands (Figure 13). The solid inclusions forming the crack-seal inclusion bands are enriched in $\mathrm{K}$ and $\mathrm{Al}$ and depleted

This article is protected by copyright. All rights reserved. 
in Si compared to the host quartz of the crack-seal bands and correspond to small clay particles (Figure 12 and Figure 13).

\section{LA-ICP-MS analysis of trace elements in quartz}

The concentrations of the main trace elements of quartz vein samples from the Shimanto Belt and the Kodiak Accretionary Complex are shown in Table 3 and plotted in Figures 14 and 15, while comparison with other examples of veins from the literature is shown in Figures 16 and 17.

As expected from EPMA maps, Al is the main trace element in quartz in terms of concentration, with values as high as $\sim 3000 \mathrm{ppm}$ (all data in wt ppm). The other main trace elements are Li, $\mathrm{Na}$ and $\mathrm{K}$, in decreasing order, in much lower concentration than Al. These monovalent cations can be incorporated in quartz as charge-compensating cations for Si-Al substitution. The plot of the monovalent cations as a function of $\mathrm{Al}$ shows a good correlation for $\mathrm{Li}$ in each of the three accretionary prisms, while $\mathrm{Na}$ and $\mathrm{K}$ do not seem correlated with Al (Figure 14).

Focusing on $\mathrm{Li}$ and $\mathrm{Al}$, there is a strong correlation between these two elements in quartz from both accretionary prisms (Figure 15A). This correlation holds despite significant differences in the Li/Al ratio between each accretionary prism (0.037 and 0.109 in Kodiak and the Shimanto Belt, respectively, Figure 15B).

The total Al or Li content incorporated in quartz is also largely different from one accretionary prism to another (Figure 15). The vein quartz from the Kodiak Accretionary Complex and the Shimanto Belt incorporate Al (Li) up to 445ppm (17ppm) and $2985 \mathrm{ppm}(421 \mathrm{ppm})$, respectively (Table 3). The vein quartz from the Shimanto is therefore more enriched in trace elements than the Kodiak Accretionary Complex.

As already seen with EPMA for Al, the luminescence is strongly correlated with the Al and Li content. In each of the three geological examples, the CL-brown, low-luminescence quartz has a much lower $\mathrm{Al}$ and Li concentration than the CL-blue, high-luminescence quartz (Figure 15). The comparison of the two examples shows a more complex pattern, as the low-luminescence quartz from the Shimanto Belt has a larger $\mathrm{Al}$ and Li concentration than the high-luminescence quartz from Kodiak.

\section{Discussion}

\section{A) Tectonic settings of veining in subduction zones}

\section{A-1) Temperature of veining}

An underlying assumption of this work is that the temperature of veining, which is unknown, can be inferred from paleotemperatures determined in the host rock (Table 1). This hypothesis is relevant only if the thermal history is relatively simple, with no more than a single peak in P-T conditions, and if the geometry and kinematics of the veins allow one to connect them, using metamorphic and structural arguments, to the peak P-T conditions of the tectonic evolution.

Higher temperature samples: The veins from the Morotsuka Group in the Shimanto Belt and from the Kodiak Central Belt in Alaska show similar features: mode I veins, sometimes with en-échelon geometry, cutting across relatively homogeneous and fine-grained pelites, and associated with shear bands at low-angle to the metamorphic foliation S1. The veins cut across S1, at the same time they are folded and shortened parallel to the Z-kinematic axis of S1 (Figure 2). In the Kodiak Central Belt, the progressive shearing of the veins parallel to S1 has also been described (Fisher and Byrne, 1990). In both the Japanese and Alaskan cases, the veins are therefore cutting across S1 and deformed by it, so the veins and the foliation must be contemporaneous. In addition, in the Morotsuka Group of the

This article is protected by copyright. All rights reserved. 
Shimanto Belt, S1 is formed of the highest grade metamorphic minerals (actinolite and white mica (Toriumi and Teruya, 1988)), and therefore is associated with the peak temperature recorded by RSCM. In the case of Kodiak, the Central Belt corresponds both to the lowest structural level and to the highest temperature (Table 2). It is also the zone of highest strain, as apparent with the rotation of the foliation towards horizontal as a result of shear (Fisher and Byrne, 1990). It is therefore likely, following previous authors, that the deformation structures observed in the Central Belt of Kodiak (including the metamorphic foliation and the contemporaneous veins), were formed during peak temperature conditions when the unit was at the depths of the accretionary wedge.

Lower temperature samples: In the Hyuga Tectonic Mélange, veining is contemporaneous with the formation of a penetrative network of top-to-the-SE shear zones, kinematically consistent with deformation during subduction (Figure 5) (Palazzin et al., 2016; Raimbourg et al., 2019). Furthermore, these shear zones contain chlorite, which is the sole metamorphic mineral. The association between deformation microstructures (including shear zones and mode I veins) and the precipitation of metamorphic minerals suggests that deformation occurred for peak temperature conditions. Another argument stems from the homogenization temperatures of fluid inclusion contained in the veins, which provide a lower bound to the temperature of formation. In the Uyak Complex of the Kodiak accretionary prism and the Hyuga Tectonic Mélange, homogenization temperatures are of the order of $290+/-20^{\circ} \mathrm{C}$ (Vrojlik, 1987) and in the $200-280^{\circ} \mathrm{C}$ (Raimbourg et al., 2014b) - $175-305^{\circ} \mathrm{C}$ (Kondo et al., 2005) range, respectively. These fluid inclusion data further show that the veins formed for temperature conditions on the order of the maximum temperatures recorded by RSCM on the host rock.

Finally, the strong top-to-the-SE shear deformation and associated pervasive veining observed in the rocks from the coherent Hyuga unit (Figure 5) is restricted to the upper portion of this unit, in the footwall of a fault separating it from the overlying Hyuga Tectonic Mélange (Raimbourg et al., 2014a). This fault contact was activated during a collisional stage in the Early Miocene (Raimbourg et al., 2017a). This stage is the main tectonic event during the Cenozoic and was responsible for thickening of the accretionary prism along several major faults. From this tectonic scenario, we propose therefore that the veining in the Coherent Hyuga unit also occurred at peak conditions of temperature.

In summary, the temperatures estimated by RSCM on host rock in the Shimanto Belt and Kodiak examples are a reliable estimate of vein formation temperatures.

\section{A-2) Relationship between veining and subduction zone deformation}

Beyond the temperature of veining, further discussion is needed to associate veining with the different domains of a subduction zone where deformation occurs. As can be inferred from structural data (Figure 5) and from their close association in space (Figures 2 and 3), the mode I veins considered here are contemporaneous with the formation of the shear zones (and the foliation in the higher temperatures cases).

The strain pattern is principally simple shear in the lower temperature examples of Hyuga Tectonic mélange and Coherent Hyuga formation, with top-to-the-trench sense of shear (Figure 5). As discussed above, the deformation/veining in the Coherent Hyuga is most likely associated with the motion along the out-of-sequence thrust faults that were activated in Early Miocene (Figure 18) (Fisher et al., 2019c; Raimbourg et al., 2017). A similar interpretation was proposed to account for deformation within the the Hyuga Tectonic mélange, which is located in the vicinity of a major fault, the Nobeoka Tectonic Line, activated during the Early Miocene collisional event (Kondo et al., 2005). Based on mapping arguments that show that the top-to-the-trench deformation within the Hyuga Tectonic mélange predates the Early Miocene deformation stage (Murata, 1998; Raimbourg et al., 2019), an alternative interpretation is that the mélange internal deformation occurred during underthrusting, along the

This article is protected by copyright. All rights reserved. 
subduction interface, similarly to other tectonic mélanges from the Shimanto Belt (Kitamura and Kimura, 2012; Onishi et al., 2001; Raimbourg et al., 2019). Similarly, the top-to-the-trench shear in Uyak Complex was interpreted as resulting from deformation during underthrusting (Byrne and Fisher, 1990; Moore and Wheeler, 1978). In addition to simple shear, the additional contribution of layerparallel extension to bulk strain in Uyak Complex (Figure 5) has been already reported in the same geological unit (Byrne and Fisher, 1990), as well as in other examples (Onishi et al., 2001). It is interpreted as reflecting the effect of a very weak décollement on top of the underthrusted sediments.

In higher temperature examples, the strain pattern includes a larger contribution of coaxial stretching (Figure 4 and 4). Nonetheless, top-to-the-trench simple shear is present, principally in the form of enéchelon set of veins, which locally evolve into shear bands (Figure 2). The respective contribution of pure and simple shear is difficult to evaluate.

In the Morotsuka formation, top-to-the-trench deformation is reported along the coast (Ujiie et al., 2018), while more coaxial fabrics are described in the equivalent formation further west (Charvet and Fabbri, 1987; Fabbri et al., 1987; Raimbourg et al., 2014). There, flattening is also apparent in isoclinal folds whose limbs are parallelized to the flat-lying, metamorphic foliation (see the structures of deformation in (Raimbourg et al., 2014)). Strain (including in particular the development of a metamorphic foliation) and metamorphic temperature are highest in the structurally lowest portion of the Morotsuka Group (Raimbourg et al., 2014; Toriumi and Teruya, 1988). We interpreted the peak of deformation and metamorphism as contemporaneous with deformation within the upper plate, near the plate interface. A similar interpretation, i.e. deformation within the upper plate near the décollement, was proposed to account for the veins and associated shear bands in the Kodiak Central Belt (Fisher and Byrne, 1990). Compared to their interpretation, our results show, though over a more restricted area, a higher contribution of coaxial extension.

All the examples presented show domains of intense and localized strain, compared to surrounding terranes. The respective locations, within an idealized subduction zone system, of these different examples, is summarized in Figure 18. Uyak Complex and Hyuga Tectonic mélange deformation is associated with underthrusting along the plate interface, Coherent Hyuga deformation with damaging in the footwall of out-of-of-sequence fault zones, Makimine and Kodiak Central Belt deformation with shear and flattening, at higher temperature, at the base of the upper wedge. We propose therefore that veining in these examples is associated with deformation along the main tectonic contacts, across a large depth range including the seismogenic zone and its downdip limit.

Beyond the spatial association between veins and zones of concentrated strain, quartz precipitation has been interpreted as directly resulting from earthquake in tectonic mélanges (Kondo et al., 2005; Yamaguchi et al., 2011; Yamaguchi et al., 2012). Similarly, at higher temperature, the two examples of veins showing crack-seal microstructures in the Shimanto Belt and the Kodiak Complex have been proposed as possibly resulting from ETS (Fisher and Brantley, 2014; Ujiie et al., 2018). The general process to connect vein growth to pulses of deformation (for example in the form of earthquakes or ETS) is, as suggested in Ujiie et al. (2018) and Fisher and Brantley (2014), that deformation of the solid results in dilatant opening of veins and fluid pressure drop, oversaturating the solution in Si and leading to quartz precipitation. In certain cases, the fluid pressure drop resulting from slip on fault is possibly so large as to result in vaporization of part of the fluid (Weatherley and Wenley, 2013).

In summary, the veins considered here were formed within the domains of concentrated deformation in subduction zones, either plate interface or out-of-sequence faults, and the precipitation of quartz within the veins is the result of the deformation events within the surrounding sedimentary rocks.

This article is protected by copyright. All rights reserved. 


\section{B) Evolution in luminescence and microstructure as a function of temperature}

In all the geological examples of mode I quartz veins described here, there is large evolution in luminescence with temperature: the luminescent, CL-blue quartz that can be observed in growth rims of euhedral quartz from Mode I veins below $300^{\circ} \mathrm{C}$ (Figure 6) is almost absent in veins formed at temperature in the range $\sim 300-350^{\circ} \mathrm{C}$ (Figure 8 ). In higher temperature samples, the precipitation of luminescent, CL-blue quartz is restricted to a small proportion of crack-seal microstructures (Figure 12 and Figure 13), which otherwise show the same low luminescence and CL-brown colors as the surrounding vein quartz (Figure 8).

A further difference is the fact that crack-seal microstructures (in the sense of antitaxial veins with bands of solid inclusions (Ramsay, 1980)) are observed only in the higher temperature examples, the Makimine Group of the Shimanto Belt (Ujiie et al., 2018) and the Kodiak Central Belt (Fisher and Brantley, 2014; Fisher et al., 1995; Fisher and Byrne, 1990). A systematic correspondence between crack-seal microstructures and temperature of veining is difficult to establish, because of the lack of temperature constraints. In Variscan syn-tectonic quartz veins in Aachen that contain crack-seal microstructures, the fluid inclusion homogenization temperatures range from 280 to $390^{\circ} \mathrm{C}$ (Becker et al., 2011). In the quartz-gold veins from Val d'Or, Abitibi, the conditions of metamorphism are lower to middle greenschist-facies conditions. From the analysis of fluid inclusion records, a temperature of formation of $\sim 350^{\circ} \mathrm{C}$ is inferred (Robert et al., 1995). One of the classical crack-seal microstructures described in Ramsay (1980) comes from the Morcles nappe, but its precise location is not given, and the paleotemperature field is not known in the corresponding area. RSCM data in nearby areas show temperatures between 250 and $350^{\circ} \mathrm{C}$ (Boutoux et al., 2016; Girault et al., 2020). The strong thermal gradient observed from the internal to the external part of the mountain belt (Girault et al., 2020) prevents any precise determination of the temperature of growth of the sample described in Ramsay (1980). Another crack-seal example in Ramsay (1980) comes from Jurassic limestones from the Windgällen area forming the autochtonous cover of the Aar massif. RSCM temperature estimates in the area yielded temperatures between 300 and $400^{\circ} \mathrm{C}$ (Nibourel et al., 2018).

In spite of these uncertainties, in all examples where a temperature can be associated with confidence to the vein formation, the typical crack-seal structures are formed for temperatures of the order of $300^{\circ} \mathrm{C}$ or higher.

\section{C) Luminescence and trace element incorporation in quartz}

C-1) Origin of the evancescent, blue luminescence in lower-temperature veins

The brown or purple luminescence is commonly observed in metamorphic quartz (Götze et al., 2001). This is the $\mathrm{CL}$ color we observed in all samples, at least for part of the quartz (Figure 6, Figure 8, Figure 10 , Figure 11). In addition, a bright, evanescent, CL blue color is specifically observed in growth rims of quartz crystals that grew at temperature of $\sim 250^{\circ} \mathrm{C}$ or lower (Figure 6, Figure 10, Figure 11), and in very restricted domains of a few crack-seal microstructures observed in quartz that grew at temperature higher than $\sim 300^{\circ} \mathrm{C}$ (Figure 8, Figure 12, Figure 13).

The short-lived blue luminescence is related to two wavelengths, around 390 and $500 \mathrm{~nm}$ (Götze and Kempe, 2008; Götze et al., 2001). This luminescence is typically observed in low-temperature hydrothermal quartz with a large Al content (Lehmann et al., 2009; Perny et al., 1992; Rusk et al., 2008). Accordingly, the EPMA maps in our lower temperature samples show a consistent match between CLblue luminescence and high Al content (Figure 10 and Figure 11), confirmed by LA-ICP-MS analyses

This article is protected by copyright. All rights reserved. 
(Figure 15). The alkali- (or hydrogen-) compensated $\left[\mathrm{AlO}_{4} / \mathrm{M}^{+}\right]$centre (where $\mathrm{M}^{+}$is a chargecompensating, monovalent cation) is likely responsible for this luminescence.

The correlation between the aluminum concentration and luminescence is nevertheless not very robust. For example, the band at $390 \mathrm{~nm}$ was detected in ultrapure quartz with $<0.1 \mathrm{ppm} \mathrm{Al}$ (Gorton et al., 1997). The analysis by Ramseyer and Mullis (1990) of a large range of vein quartz from the Alps shows that only quartz crystals containing more than $50 \mathrm{ppm}$ Al display a short-lived blue cathodoluminescence. Above this threshold, there is no correlation between the intensity of the luminescence and Al concentration. Similarly, Lehmann et al. (2009) distinguish a low-luminescent, Alpoor quartz from a high-luminescent, Al-rich one, with a threshold at $500 \mathrm{ppm}$. In the high $\mathrm{Al}$ concentration range, the density of luminescent intrinsic defects (non bridging $\mathrm{O}-$, O- and Si-vacancies) is decorrelated with the Al concentration.

The respective role of the different charge-compensating cations $(\mathrm{Na}, \mathrm{K}, \mathrm{Li}, \mathrm{H})$ is also difficult to determine. On the basis of comparison of different microstructures of quartz, Ramseyer and Mullis (1990) discarded Li+ as possibly causing the luminescence. On the other hand, $\mathrm{Na}+$ and $\mathrm{K}+$ do not correlate with Al concentration in the hydrothermal quartz considered here (Figure 14) or in the quartz crystals from volcanic rocks (Watt et al., 1997). In vein quartz from the Swiss Alps, $\mathrm{Li}^{+}$and $\mathrm{H}^{+}$are the main compensating cations for Al (Perny et al., 1992). In our samples, there is a clear correlation between Al and Li (Figure 14) and the luminescence (Figure 15). Compiling the literature data from hydrothermal veins confirms this conclusion (Figure 16). In most samples, high luminescence is correlated with high level of $\mathrm{Al}^{3+}+\left(\mathrm{Li}^{+} / \mathrm{H}^{+}\right)$substitution in quartz. Furthermore, similar to our samples, the high luminescence is restricted to the lower-temperature range of the samples investigated.

\section{C-2) Trace element incorporation in quartz:}

Because of charge compensation, the concentrations of the main impurity cations in quartz follow the relationship $\mathrm{Li}^{+}+\mathrm{H}^{+}+\mathrm{K}^{+}+\mathrm{P}^{5+}=\mathrm{Al}^{3+}+\mathrm{B}^{3+}$ (Baron et al., 2015; Müller and Koch-Müller, 2009). In high-T high-P experiments by Frigo et al. (2016), aluminum is the major cation, with a concentration that correlates to some extent with Li, especially at high Al content, with a Li/Al atomic ratio of $\sim 0.6$. The large compilation of metamorphic, magmatic and hydrothermal quartz from Norway shows a large scatter in Li vs. Al plots (Müller and Koch-Müller, 2009). Restricting the analysis to hydrothermal quartz, the most abundant elements are Al and Li (Müller et al., 2003). Similarly, Al and Li are the main impurities in hydrothermal vein quartz from the Alps (Jourdan et al., 2009). Our measurements confirm that $\mathrm{Al}$ and $\mathrm{Li}$ are the cations preferentially incorporated in quartz during low-temperature hydrothermal growth, with concentrations of Al that can reach 3000 ppm (Figure 14).

Additionally, in hydrothermal quartz from the Alps, Al and Li concentrations show a relatively good correlation, with Li/Al atomic ratios between 0.5 and 0.7 or 0.8 (Jourdan et al., 2009). In our study, the three cases investigated exhibit a very good correlation between Al and Li concentration, but the atomic ratio is quite variable from one case to another (Figure 15). The atomic ratios are between 0.14 to 0.54 (a factor of 3.86 applies to convert wt ratio to atomic ratio), i.e. significantly lower than in Jourdan et al. (2009). The plot of all literature data shows that Li/Al atomic ratios are quite variable from one example to another (Figure 16), but in any case lower than one.

$\mathrm{Li}$ is not able to compensate for the charge deficit of $\mathrm{Si}-\mathrm{Al}^{3+}$ substitution, while $\mathrm{Na}$ and $\mathrm{K}$ are in small concentrations and uncorrelated to Al (Figure 14). Therefore, according to the equation above, the rest of the $\mathrm{Al}^{3+}$-related charge compensation must result from $\mathrm{H}^{+}$incorporation, as reported in other studies (Jourdan et al., 2009; Perny et al., 1992). Nonetheless, the respective incorporation of $\mathrm{H}^{+}$ and/or $\mathrm{Li}^{+}$to compensate for the Si-Al charge deficit is dependent on the Al concentration (compare Figure 17A and B). The samples with high Al concentration show the highest Li/Al atomic ratio (Figure

This article is protected by copyright. All rights reserved. 
$17 \mathrm{~A})$, up to an atomic ratio of 0.93 , i.e. close to 1 . The same increase in relative uptake of Li with respect to $\mathrm{H}$ is observed in our samples (compare Figure 15A and $B$ ).

In summary, Al is the main impurity incorporated in hydrothermal quartz. The charge imbalance associated with this incorporation is compensated by the uptake of $\mathrm{Li}$ and $\mathrm{H}$, with a variable ratio.

\section{D) Interpretation of the luminescence in terms of growth conditions}

The coexistence of two types of luminescence in alternating growth rims poses the questions of which physico-chemical parameters control the luminescence and how do these parameters vary during crystal growth.

Neither the pressure, the temperature, or the nature of the solvent in the fluid seem to influence the intensity of the short-lived blue luminescence (Ramseyer and Mullis, 1990; Rusk et al., 2008). This statement is further justified by the same homogenization temperatures of fluid inclusions contained in CL-blue and CL-brown growth rims (Raimbourg et al., 2015).

Other studies have pointed out the influence of the composition of the fluid. Al variable incorporation in quartz might be controlled by changes in the $\mathrm{pH}$ of the solution, as it strongly influences $\mathrm{Al}$ complexation and its concentration in the solution (Mookherjee et al., 2014; Perny et al., 1992; Rusk et al., 2008). But the large variations in pH advocated in Rusk et al. (2008) are relevant in the context of magma-derived hydrothermal alteration and associated ore genesis. In the low grade domains of subduction zones and accretionary prisms, such large changes in $\mathrm{pH}$ are less likely, so that the $\mathrm{pH}$ does not seem to be the controlling factor for the alternating precipitation of CL-blue and CL-brown quartz.

Alternatively, the growth rate and the growth mode (i.e., stationary or cyclic) have a large influence on the luminescence (Götze et al., 2001; Perny et al., 1992; Ramseyer and Mullis, 1990). Ihinger and Zink (2000) have shown that faster-growing crystal facets incorporate more Al than slower-growing ones and concluded that there is a relationship between $\mathrm{Al}$ incorporation and crystal growth rate.

This effect of growth rate is further supported, in the samples considered here, by the very large variations in the density of fluid inclusions that correlate with the luminescence: the CL-blue growth rims are much richer in fluid inclusions than the CL-brown ones (Figure 6, Figure 10, see also (Raimbourg et al., 2018; Raimbourg et al., 2015)). This contrast in fluid inclusion density points to significantly higher growth rates of the CL-blue rims, which prevents defect-free growth of the crystal.

Additionally, further insights can be gained from the comparison of growth zoning patterns in hydrothermal quartz with those that can be observed in olivine crystallized from a melt. Patterns of phosphate zoning in olivine grown from a melt have been interpreted as the result of rapid growth of the crystal (i.e., surface-controlled growth), overcoming the diffusion of $\mathrm{P}$ away from the growing crystal (Welsch et al., 2013, 2014). In contrast, low P concentrations are observed in the case of diffusion-controlled growth of olivine, when the growth of the crystal is slow enough for the efficient diffusion of the $\mathrm{P}$ away from the crystal. Similarly, framboidal pyrite with a large concentration of impurities are grown from a fluid phase in surface-controlled régime, while euhedral pyrite with a lower impurity content have formed in diffusion-controlled régime (Merinero et al., 2009).

The same concept might apply here: the CL-blue quartz grew in surface-controlled régime, with high growth rates and abundant impurities (fluid inclusions, Al+compensating cation substitution for $\mathrm{Si}$ ), while the CL-brown quartz grew at a much lower rate, in a diffusion-controlled regime, where efficient $\mathrm{Al}$ and Li diffusion away from the growing crystal occurs.

This article is protected by copyright. All rights reserved. 
The reason for the differences in growth rate of quartz might be related to variations in super saturation levels, following the models of olivine or pyrite crystals (Merinero et al., 2009; Welsch et al., 2014). Similarly, Mullis (1987) postulated that the rapid quartz growth was caused by a sudden drop in fluid pressure, causing phase separation in the fluid (the single-phased mixed fluid separates into methane-rich and water-rich fluids) and precipitation of quartz. The equilibrium concentration of dissolved silica decreases with pressure decrease at constant temperature (Anderson and Burnham, 1965; Fournier and Potter, 1982; Morey et al., 1962). Therefore, a sudden pressure drop leads to supersaturation of silica and enhanced growth of quartz from the solution.

In conclusion, the formation of Al- and Li-rich, CL-blue quartz is probably related to enhanced growth rates, which involves a large increase in the magnitude of the driving force for precipitation. In turn, the most likely scenario to account for such stages of rapid growth is rapid pressure drops, leading to supersaturation of silica and increased rates of quartz precipitation.

\section{E) Model of pore fluid pressure variations in subduction zones}

\section{E-1) Evidence for fluid pressure variations:}

The precipitation of highly luminescent, CL-blue, and Al-Li-rich quartz, is best explained, as seen above, as the result of rapid fluid pressure drops. For cyclical precipitation of the $\mathrm{CL}-$ blue growth rims to occur, they must alternate with periods of recovery of the fluid pressure, where CL-brown growth rims would precipitate, at a much slower pace.

Further arguments for fluid pressure variations during precipitation of hydrothermal quartz are provided by trapped fluid inclusions. Several studies have argued for large (up to 150-200 MPa) variations in the paleopressure conditions of the fluid that is contained as inclusions within hydrothermal quartz grown in veins, in low-grade terranes from collision or subduction settings (Herrington and Wilkinson, 1993; Mullis, 1988; Robert et al., 1995; Vrojlik, 1987). Fluid inclusion data might be questionable, because post-entrapment reequilibration processes can affect the P-V-T properties of the fluid (Raimbourg et al., 2018; Sterner and Bodnar, 1989; Vityk and Bodnar, 1995; Vityk et al., 1994). Methane-rich fluid inclusions are much less prone to reequilibration than water-rich fluid inclusions (Vityk et al., 1994). When restricting the study to methane-rich fluid inclusions, large ( $150 \mathrm{MPa}$ ) variations in fluid pressure are still recorded in the inclusions (Raimbourg et al., 2017b; Vrojlik, 1987). The geochemical scenario developed above, where quartz precipitation in veins results from fluid pressure variations, is therefore supported by fluid inclusion data.

E-2) Depth changes in the amplitude of fluid pressure variations

The samples considered here span a temperature range from 200 to $350^{\circ} \mathrm{C}$. Such range corresponds to the transition, in terms of mechanical behavior, from the seismogenic portion to the deeper, aseismic portion of the plate interface, i.e. the downdip limit of the seismogenic zone (Hyndman et al., 1997; Oleskevich et al., 1999). The base of the seismogenic zone is also the locus of ETS generation (Audet and Kim, 2016). As discussed above, all the veins considered were formed in zones of localized strain, such as the plate interface or out-of-sequence thrust, and quartz precipitation is probably the result of the deformation of the surrounding rock matrix. In particular, the higher temperature samples studied here contain crack-seal microstructures. They are similar and were collected in the same area as Ujiie et al. (2018) and Fisher and Brantley (2014), in the Morotsuka Group of the Shimanto Belt and in the Kodiak Central Belt, respectively. Crack-seal microstructures were interpreted in these studies as a possible record of ETS based on kinematics, temperature of formation, and recurrence interval.

This article is protected by copyright. All rights reserved. 
The comparative study of lower $\left(\sim 200-250^{\circ} \mathrm{C}\right)$ and higher $\left(\sim 300-350^{\circ} \mathrm{C}\right)$ temperature quartz veins shows, from the contrast in luminescence, large differences in the incorporation of $\mathrm{Al}$ and $\mathrm{Li}$ in hydrothermal quartz as a function of temperature. Veins formed at $\sim 250^{\circ} \mathrm{C}$ show two types of luminescence, including a bright, blue luminescence that corresponds to high Al and Li contents (Raimbourg et al., 2018). Such blue luminescence is the most visible when mode I veins contain euhedral crystals with growth rims, such as described in the present work, but more generally most of quartz mode I veins show such a luminescence (Raimbourg et al., 2015). In contrast, veins formed at $\sim 350^{\circ} \mathrm{C}$ are composed principally of a homogeneous, CL brown quartz (Figure 6, Figure 8 (Raimbourg et al., 2018)). In a similar study, periodic patterns of growth are observed in quartz from samples precipitated at temperature conditions of $\sim 300^{\circ} \mathrm{C}$, while in the sample precipitated at $400^{\circ} \mathrm{C}$, only a single type of crystal is formed, with a low luminescence and a low concentration in impurity (Jourdan et al., 2009).

On the basis of (i) the inferred relationships between quartz growth and fluid pressure variations and (ii) the tectonic interpretation of the veins in the framework of subduction zone, we propose in Figure 18 a model of fluid pressure variations across depth. In the lower temperature régime, the large variations in $\mathrm{Al}$ incorporation in veins are the expression of large fluid pressure variations, possibly as a result of earthquakes (Figure 18). In contrast, the quasi-absence of CL-blue quartz in higher temperature veins is somehow puzzling, as the crack-seal microstructures they contain (Fisher and Brantley, 2014; Ujiie et al., 2018), as well as their fluid inclusion record (Nishiyama et al., 2020; Ujiie et al., 2018), suggest cyclical changes in fluid pressure. Compared to lower temperature samples, the absence of CL-blue quartz could be related to several factors, such as the higher temperature, a depletion in $\mathrm{Al}$ in the fluid, or smaller fluid pressure variations.

The difference in temperature between lower and higher T samples is relatively small, $\sim 75^{\circ} \mathrm{C}$, so that its effect on the diffusion coefficient of solutes in the fluid is limited. For example, the diffusion coefficient of silica in water is only increased by a factor of 2 or less (Nakashima, 1995), i.e. much lower than the increase of the trace element content by up to 3 orders of magnitude between CL-brown and CL-blue quartz.

Another explanation could be a large change in the Al-content of the fluid between lower and higher temperature samples. There is nevertheless no large mineralogical change with increasing temperature that would imply a significant depletion in Al in the fluid in higher temperature samples (Fagereng et al., 2018). For example, the reaction described in Kameda et al. (2011), in similar rocks and for similar temperatures, does not induce any change in Al content of the fluid nor any change in the phyllosilicates forming the parageneses (chlorite and mica).

It follows that the absence of CL-blue quartz in the higher temperature samples might result from a smaller amplitude of fluid pressure variations than in lower temperature samples (Figure 18). Even within the crack-seal microstructures, the $\mathrm{CL}$-blue patches (the triangles in Figure $8 \mathrm{~A}$ and $\mathrm{B}$ ) are very restricted, so that the fluid pressure cycles accompanying cracking then sealing cycles might have limited amplitude compared to lower temperature samples. Nonetheless, crack-seal microstructures are the only domains where the CL-blue luminescence is locally present, which could correspond to events of high strain during ETS, whereas the rest of the vein would grow in steady-state conditions.

The conclusions about the limited amplitude of fluid pressure variations in the higher temperature samples are to some extent contradictory to the large range of vapor/liquid ratio or homogenisation temperatures in fluid inclusions from the Morotsuka unit (Nishiyama et al., 2020; Ujiie et al., 2018). But, as discussed above, water-rich fluid inclusions are possibly affected by various reequilibration processes, even more in deformed zones at temperature where plastic deformation is activated. Postentrapment reequilibration is therefore a possible interpretation for the large variations in fluid inclusion data, which would deviate then from the record of past pressure.

This article is protected by copyright. All rights reserved. 
The model proposed in Figure 18 summarizes these interpretations about the fluid pressure variations in zones of concentrated deformation of a subduction system, across the depth range encompassing the seismogenic domain and its downdip limit. This model, which compares different depth domains, is only qualitative. What is shown are fluid pressure variations in time and not fluid overpressure amplitude. The amplitude of fluid overpressure may be smaller at seismogenic depths than in the deeper domain of ETS generation (Saffer and Tobin, 2011).

The smaller fluid pressure fluctuations near the downdip limit of the seismogenic zone might reflect the onset of quartz plastic deformation around $\sim 300^{\circ} \mathrm{C}$ (Behr and Platt, 2011; Stipp et al., 2002), which prevents large differential stress (as might result from a large drop in pressure within rock cavities) to be sustained. In other words, a plastically weak rock matrix would deform easily enough not to let the fluid within its cavity drop to a pressure that deviates significantly from the ambient solid pressure. Although the precise range of the brittle to viscous evolution of quartz is not well constrained, our own analysis of Shimanto Belt rheological behavior across the observed temperature gradient shows that samples deformed at $\mathrm{T}^{\sim} 250^{\circ} \mathrm{C}$ do not deform plastically, while the quartz crystals from domains at $\mathrm{T}^{\sim} 350^{\circ} \mathrm{C}$ show microstructures of recrystallization and the development of a crystallographic preferred orientation (Palazzin, 2016). Alternately, smaller fluid pressure variations at ETS might also results from the lower strain amplitude of deformation events, or to much lower variations in stresses (Ide et al., 2007; Schwartz and Rokosky, 2007), compared to normal earthquakes in the seismogenic zone.

\section{Conclusions}

1-Quartz veins from a range of geological examples of low-grade terranes in subduction settings have geometries and kinematics that allow most of them to be associated with peak burial or with the deep evolution in the upper wedge. In such cases, host rock maximum temperature derived from RSCM can therefore be assigned with confidence to vein formation conditions.

2-Quartz veins from these various examples show geochemical characteristics that vary systematically as a function of temperature of formation. Lower-temperature $\left(\sim 200-260^{\circ} \mathrm{C}\right)$ quartz showing growth microstructures, exhibits alternations of $\mathrm{CL}$-blue, high luminescence, $\mathrm{Al}$ - and Li-rich, fluid-inclusionsrich rims and $\mathrm{CL}$-brown, low luminescence, trace element-poor, fluid-inclusions-poor rims. Higher temperature $\left(\sim 300-350^{\circ} \mathrm{C}\right)$ quartz is almost exclusively $\mathrm{CL}$-brown, with a low luminescence, and is poor in trace elements and fluid inclusions.

3-Crack-seal textures in the higher temperature quartz are the only microstructures where the luminescent and trace element-rich quartz are present. Yet this type of quartz is not observed in all crack-seal microstructures, and when present, its spatial extent is very limited.

4-The trace element analysis of quartz shows a first-order clear correlation between luminescence patterns and $\mathrm{Al}$ and $\mathrm{Li}$ concentration variations. Al and Li concentration are correlated, with a Li/Al ratio that increases when trace element concentration increases. Li concentration is not sufficient to compensate for all the charge deficit of the substitution of $\mathrm{Si}$ by $\mathrm{Al}$; we suggest that $\mathrm{H}^{+}$compensates for the difference.

5-The geochemical features of quartz are interpreted as reflecting the conditions of precipitation, in particular the fluid pressure conditions. The fluid inclusions-rich and trace elements-rich quartz is interpreted as reflecting out of equilibrium, rapid growth, following a large pressure drop, while the fluid inclusions-poor and trace elements-poor quartz has grown under steady-state conditions.

6-Following this interpretation, the geochemical contrast between quartz formed at lower and higher temperature reflects a large contrast in the hydrological system along depths in subduction zones, in

This article is protected by copyright. All rights reserved. 
the domains of where strain is concentrated (i.e. the subduction interface and out-of-sequence thrusts). At seismogenic depths, the fluid pressure undergoes large variations, possibly as a result of earthquakes, resulting in the precipitation of the two types of quartz. In the transition zone at the downdip limit of the seismogenic zone, the fluid pressure is relatively constant. The only exceptions are crack-seal microstructures, which may reflect fluid pressure changes associated with ETS. The amplitude of such fluid pressure changes in the ETS domain is probably much more limited compared to the seismogenic domain.

\section{Figures captions}

Figure 1: Geological map of the Shimanto Belt on Kyushu, Japan (left) and of the Kodiak Accretionary Complex, Alaska, USA (right), with the location of the quartz vein samples analyzed in this study.

Figure 2 : Mode I quartz vein structures from Morotsuka Group in the Shimanto Belt (A and B) and from the Kodiak Central Belt in Alaska ( $C$ and $D)$. In all examples, veins cut the metamorphic foliation S1 at a high-angle. In (A) and (C), veins are folded as a result of shortening perpendicular to $S 1$. In $(B)$ and $(D)$, veins form en échelon pattern, with rotation of the internal part of each vein, consistent with top-to-the-S or SE sense of shear. In (C), veins form in the vicinity of shear-zones cutting across $S 1$. The shear zones are also filled with quartz. The blue arrows point to veins of the same type as the ones studied here. All photographs in the kinematic X-Z plane. Outcrops: (A)-18NOB23B, (B)-18NOB13, (C)-2019KO32A and (D)2019 KO30.

This article is protected by copyright. All rights reserved. 
Figure 3: Mode I quartz vein structures from the Coherent Hyuga (A), the Hyuga Tectonic Mélange (B), in Japan, and Uyak Formation (C), in Alaska (shown by the blue arrows). (A) Quartz veins in sandstone lenses deformed by a top-to-the-SE shear zone (B) Quartz veins in boudinaged sandstone lenses, in the vicinity of a top-to-the-SE shear band. (C) Quartz veins in the necked parts of boudinaged chert layers. All photographs in the kinematic X-Z plane.

Figure 4: (1) and (1') Structures of mode I quartz veins studied here. Mode I veins are orientated perpendicular to bedding or the metamorphic foliation plane and perpendicular to the X-kinematic axis. They form preferentially in the necked domains of sandstone lenses (a), sometimes in correspondence with shear zones (b). Veins also form in the vicinity of quartzinfiltrated shear bands, branching from the main shear plane (c), as sets of en-échelon veins (d) or as isolated veins (e). Quartz precipitates within shear bands, in which case it shows a fibrous structure parallel to the direction of motion (f). In (1), the bulk strain is simple shear, while in (1') strain is pure shear. At the microscopic scale, growth rims form in euhedral quartz in the core of Mode I veins filling boudin necks (2), while crack-seal textures are observed in veins cutting across the shale matrix (3).

Figure 5: Structural data of veins and associated deformation features in the Shimanto Belt (top) and Kodiak island (bottom), for both lower temperature (left) and higher temperature (right) units. All the samples studied are mode I veins at a large angle to the foliation plane. In the Kodiak Central Belt, the sample is a small tension crack perpendicular to a macroscopic quartz-filled shear zone indicated in the plot. For the Uyak Complex site 2019KO24, the left plot shows data in the present geometry, while the right plot show data after rotating the foliation plane to horizontal. The number on each plot refers to the number of veins. All stereoplots in lower hemisphere, with arrows pointing to the motion of the hanging wall.

Figure 6 : (Left) Optical microscope and (right) CL images of quartz veins showing growth rims with alternating CL-blue, high luminescence and CL-brown, low luminescence (indicated respectively by blue and brown triangles). Zones with an extremely high density of fluid inclusions appear much darker in optical microscope images. In many instances $(A, C)$, the $C L$ blue rims coincide with domains of quartz extremely rich in fluid inclusions. ( $A$ ) Coherent Hyuga from the Shimanto Belt (2018NOBO2E), (B) Hyuga Tectonic Mélange from the Shimanto Belt (HN51b), (B) Uyak Complex from the Kodiak Island (2019K032).

Figure 7 : Close-up view of the contrast in fluid inclusion density between the growth rims of the sample in Figure 6A. Optical microscope.

Figure 8: (Left) Optical microscope and (right) CL images of crack-seal microstructures in quartz veins. The quartz in these veins has predominantly a CL-brown, low luminescence, except for restricted domains within the quartz bands of crack-seal veins (e.g. the white triangles in $(A)$ and $(B))$. Note in $(C)$ the presence of a later-stage, $C L$-blue, crosscutting veinlet. (A) and (B) : Kodiak Central Belt (2019KO-32), (C): Morotsuka Group from the Shimanto Belt (2018NOB23B).

Figure 9: Typical Raman spectra of carbonaceous matter in lower and higher temperature units of the Shimanto Belt and Kodiak accretionary prism. The measured spectrum (black line) is modelled (red line) as the sum of five Lorentzian functions (gray lines, labelled D4, G, D3, G and D2), following Lahfid et al. (2010).

This article is protected by copyright. All rights reserved. 
Figure $10:(A)$ Optical microscope and (B) cathodoluminescence image of growth rims in quartz grains from the Shimanto Belt sample 2018NOB-2E. (C) EPMA maps of aluminum (left) and potassium (right) of the rectangle shown in $(A)$ and $(B)$. The low-luminescence rims correspond to a lower aluminum concentration. The fluid inclusions are the most abundant in the CL-blue and brightest rims, which corresponds also to the highest Al concentrations. Note also the brightest spots in the Al map, which correlate with large $K$ concentrations, and also with fluid inclusions.

Figure 11 : (A) Optical microscope and (B) cathodoluminescence image of growth rims in quartz grains from the Uyak Complex from Kodiak Island (2019KO-24A). (C) EPMA maps of aluminum (left) and potassium (right) of the rectangle shown in ( $A$ ) and (B). The low-luminescence rims correspond to a lower $A$ l concentration. $A$ thin growth rim, enriched in $A l$, is shown by blue arrows in (C). Note the brightest spots in $A$ l map, which correlate with large $K$ concentrations, and also with fluid inclusions. The CL contrast, as well as the Al concentration differences, are much smaller than on the Shimanto Belt sample (Figure 10). On (C) left, the lower bound of the greyscale has been adjusted to highlight the variations within the quartz.

Figure 12 : Crack-seal microstructure in quartz from the Shimanto Belt (sample 18NOB23B). (A) Optical microscope and (B) CL image. Some of the grains, which are all elongated in the N$S$ direction of the figure, contain successive bands of solid inclusions in their core, forming crack-seal microstructures. The blue luminescence is restricted to the quartz within the crackseal structures. (C) EPMA map of Al concentration. There is a sharp contrast in Al concentration between the Al-richer quartz within the crack-seal microstructure and the Al-poorer quartz outside, within the same quartz grain. Note that the black color on the table on the right corresponds to a non-zero concentration, in order to highlight the Al concentration contrast within quartz.

Figure 13: Crack-seal microstructure in quartz from the Kodiak Formation (sample 2019KO32A). (A) Optical microscope and (B) CL image and (C) EPMA Al map from the two zones shown in $(A)$. In (C) the red domains (highest Al content) correspond to clay solid inclusion bands, while the quartz shades are between blue and turquoise. The crack-seal structures highlighted by the dark, solid inclusion bands $(A)$ host quartz that shows, for a portion of it, a $C L$-blue luminescence absent elsewhere in the vein (B). The CL-blue luminescence corresponds to a higher Al content in quartz (C). The CL-blue and Al-rich domains in quartz bands of crackseals show a patchy and complex spatial distribution, with local alternation of rims of Al-rich and Al-poor quartz (C-bottom).

Figure 14: In situ LA-ICP-MS concentration of monovalent cations $\mathrm{Na}, \mathrm{K}$ and $\mathrm{Li}$ as a function of $A l$, in quartz from veins collected in the Shimanto Belt and Kodiak Island. Li is the monovalent cation with the largest concentration, and the only one whose concentration shows a correlation with Al concentration. All data are listed in Table 3.

Figure 15: Compilation of Li vs. Al concentration (in wt ppm) of hydrothermal quartz measured by LA-ICP-MS in the Shimanto Belt and Kodiak accretionary prism. (A) all data points, (B) data points for $A l<800 \mathrm{ppm}$. In all three geological examples, the CL-brown, low luminescence quartz, has lower Al and Li concentration than the CL-blue, high-luminescence quartz. In the two geological examples, the concentrations align along relatively well-defined correlation lines, which vary significantly from one case to another. Note that the analyses were restricted

This article is protected by copyright. All rights reserved. 
to domains with zero or low density of fluid inclusions, in order to not mix the fluid and host quartz trace element signals.

Figure 16: Compilation of Li vs. Al concentrations (in wt ppm) of hydrothermal quartz measured by LA-ICP-MS, from literature data and this study. Similar to the examples studied here, the low-luminescence quartz has a lower concentration in Al and Li than the high luminescence quartz. Additionally, the hydrothermal quartz formed at relatively higher temperature (i.e. $400^{\circ} \mathrm{C}$ and above) has a low concentration in Al and Li. (A) All data points and (B) data points for Al <500ppm. References: Alpine samples (Gigerwald, Grosstal and Vättis): (Jourdan et al., 2009); Norway quartz: (Müller and Koch-Müller, 2009); Hakos mountains (Greece): (Müller et al., 2003); accretionary prisms : this study.

Figure 17 : Li/Al ratio in all hydrothermal quartz measured by LA-ICP-MS from literature data and this study. (A) All data points, (B) data points for Al <200ppm. Li/Al ratio is higher for larger Al concentration (left) than for low ones (right).

Figure 18: Model of vein quartz geochemical variations as a function of temperature, in subduction zones. Vein quartz at temperatures below $300^{\circ} \mathrm{C}$ show alternation of Al-rich and Al-poor growth rims. Vein quartz formed at temperatures above $300^{\circ} \mathrm{C}$ show an homogeneous, Al-poor quartz. The crack-seal microstructures, which were observed only in the higher temperature samples, show also a low concentration in Al, except in restricted domains. We interpreted these variations in terms of fluid pressure variations. At lower temperature, corresponding to seismogenic zone, large fluid pressure variations occurs, possibly as a result of earthquakes. At the downdip limit of the seismogenic zone, variations in fluid pressure are of much smaller amplitude, even if cyclical microstructures such as crack-seal microstructures, are observed. These cyclical microstructures might be associated to cyclical deformation events, such as ETS.

This article is protected by copyright. All rights reserved. 


\section{Tables}

Table 1 : Location of the sample analyzed in this study and associated paleatemperatures determined by RSCM, following the calibration by Lahfid et al. (2010).

Table 2 : Temperatures derived from RSCM analysis along the Big Waterfall Bay transect, NE of Afognak Island, Kodiak Accretionary Complex, Alaska.

Table 3 : Trace element concentration, in wt ppm, of Li, Al, Na and K, determined by LA-ICP-MS, of vein quartz from the Helminthoides Flysch, from the Shimanto Belt and from Kodiak Island. The analysis given here were restricted to volumes of quartz with zero or low density of fluid inclusions. The sign ""refers to an analysis that is either below detection limit, or that was excluded as the ablation profile showed irregular spikes.

\section{Acknowledgements}

The autors acknowledge support from both LabEx VOLTAIRE (ANR-10-LABX-100-01) and EquipEx PLANEX (ANR-11-EQPX-0036) projects. The dataset of sample locations, host-rock temperatures and LA-ICP-MS analysis is available in repository EarthChem (doi:10.26022/IEDA/111566). This is IPGP contribution XXXX.

\section{References}

Ague, J.J. (2015) Fluid flow in the deep crust, Treatise on Geochemistry: Second Edition, pp. 195-228. Anderson, G.M. and Burnham, C.W. (1965) The solubility of quartz in supercritical water. Amer. J. Sci. 263, 494-511.

Audet, P. and Kim, Y. (2016) Teleseismic constraints on the geological environment of deep episodic slow earthquakes in subduction zone forearcs: A review. Tectonophysics 670, 1-15.

Audet, P. and Schwartz, S.Y. (2013) Hydrologic control of forearc strength and seismicity in the Costa Rican subduction zone. Nature Geoscience 6, 852-855.

Baron, M.A., Stalder, R., Konzett, J. and Hauzenberger, C.A. (2015) OH-point defects in quartz in Band Li-bearing systems and their application to pegmatites. Phys. Chem. Minerals 42, 53-62.

Becker, S., Hilgers, C., Kukla, P.A. and Urai, J.L. (2011) Crack-seal microstructure evolution in bimineralic quartz-chlorite veins in shales and siltstones from the RWTH-1 well, Aachen, Germany. J. Struct. Geol. 33, 676-689.

Behr, W. and Platt, J.P. (2011) A naturally constrained stress profile through the middle crust in an extensional terrane. Earth Planet. Sci. Lett. 303, 181-192.

Beyssac, O., Goffé, B., Chopin, C. and Rouzaud, J.N. (2002) Raman spectra of carbonaceous material in metasediments: a new geothermometer. J. Metamorph. Geol. 20, 859-871.

Boutoux, A., Bellahsen, N., Nanni, U., Pik, R., Verlaguet, A., Rolland, Y. and Lacombe, O. (2016)

Thermal and structural evolution of the external Western Alps: Insights from (U-Th-Sm)/He thermochronology and RSCM thermometry in the Aiguilles Rouges/Mont Blanc massifs.

Tectonophysics 683, 109-123.

Brantley, S.L., Fisher, D.M., Deines, P., Clark, M.B. and Myers, G. (1997) Segregation veins: evidence for the deformation and dewatering of a low-grade metapelite, in: Holness, M.B. (Ed.), Deformationenhanced fluid tranport in the Earth's crust and mantle. Chapman and Hall, London, pp. 267-288.

Byrne, T. and Fisher, D. (1990) Evidence for a weak and overpressured decollement beneath sediment-dominated accretionary prisms. J. Geoph. Res. 95, 9081-9097.

Charvet, J. and Fabbri, O. (1987) Vue générale sur l'orogenèse Shimanto et l'évolution tertiaire du Japon sud-ouest. Bull. Soc. Geol. France 8, 1171-1188 (in french with english abstract).

This article is protected by copyright. All rights reserved. 
Connelly, W. (1978) Uyak Complex, Kodiak Islands, Alaska: A Cretaceous subduction complex. GSA Bull. 89, 755-769.

Cox, S.F. (2001) Fluid flow in mid- to deep crustal shear systems: Experimental constraints, observations on exhumed high fluid flux shear systems, and implications for seismogenic processes. Earth Planets Space 54, 1121-1125.

Cox, S.F., Etheridge, M.A. and Wall, V.J. (1986) The role of fluids in syntectonic mass transport, and the localization of metamorphic vein-type ore deposits. Ore Geology Reviews 2, 65-86.

Elkhoury, J.E., Brodsky, E.E. and Agnew, D.C. (2006) Seismic waves increase permeability. Nature 441, 1135-1138.

Fabbri, O., Charvet, J. and Faure, M. (1987) Phase ductile à vergence nord dans la zone Shimanto de Kyushu (Japon SW). C. R. Acad. Sc. Paris 304 serie II, 923-927 (in french with english abstract).

Fagereng, A., Diener, J.F.A., Ellis, S. and Remitti, F. (2018) Fluid-related deformation processes at the up- and downdip limits of the subduction thrust seismogenic zone: What do the rocks tell us? GSA Spec. Pap. 534, 187-215.

Fagereng, A., Remitti, F. and Sibson, R.H. (2011) Incrementally developed slickenfibers - geological record of repeating low stress-drop seismic events? Tectonophysics 510, 381-386.

Fisher, D.M. (1985) Strain variations within an accreted slate belt, Kodiak Islands, Alaska. GSA Abstracts with Programs 17.

Fisher, D.M. and Brantley, S.L. (1992) Models of quartz overgrowth and vein formation: deformation and episodic fluid flow in an ancient subduction zone. J. Geophys. Res. 97, 20,043-020,061.

Fisher, D.M. and Brantley, S.L. (2014) The role of silica redistribution in the evolution of slip instabilities along subduction interfaces: Constraints from the Kodiak accretionary complex, Alaska. J. Struct. Geol. 69B, 395-414.

Fisher, D.M., Brantley, S.L., Everett, M. and Dzonik, J. (1995) Cyclic fluid flow through a regionally extensive fracture network within the Kodiak accretionary prism. J. Geophys. Res. 100, 12,881812,894 .

Fisher, D.M. and Byrne, D.E. (1992) Strain variation in an ancient accretionary wedge: implications for forearc evolution. Tectonics 11, 330-347.

Fisher, D.M. and Byrne, T. (1987) Structural evolution of underthrusted sediments, Kodiak Islands, Alaska. Tectonics 6, 775-793.

Fisher, D.M. and Byrne, T. (1990) The character and distribution of mineralized fractures in the Kodiak Formation, Alaska: Implications for fluid flow in an underthrust sequence. J. Geophys. Res. 95, 9069-9080.

Fisher, D. M., Hooker, J. N., and Oakley, D. O. S., (2019) Numerical models for slip on the subduction interface motivated by field observations: Lithosphere, v. 11, no. 3, p. 322-332.

Fisher, D. M., Smye, A. J., Marone, C., Van Keken, P. E., and Yamaguchi, A. (2019b) Kinetic models for healing of the subduction interface based on observations of ancient accretionary complexes: $\mathrm{G}$ cubed, v. 20, p. 1-19.

Fisher, D.M., Tonai, S., Hashimoto, Y., Tomioka, N. and Oakley, D. (2019c) K-Ar Dating of Fossil Seismogenic Thrusts in the Shimanto Accretionary Complex, Southwest Japan. Tectonics 38, 38663880.

Fournier, R.O. and Potter, R.W.I. (1982) An equation correlating the solubility of quartz in water from $25^{\prime \prime}$ to $900^{\circ} \mathrm{C}$ at pressures up to 10,000 bars. Geochimica et Cosmochimica Acta 46, 1969-1973.

Frigo, C., Stalder, R. and Hauzenberger, C.A. (2016) OH defects in quartz in granitic systems doped with spodumene, tourmaline and/or apatite: experimental investigations at 5-20 kbar. Phys. Chem. Minerals 43, 717-729.

Girault, J.-B., Bellahsen, N., Boutoux, A., Rosenberg, C., Nanni, U., Verlaguet, A. and Beyssac, O. (2020) The 3-D Thermal Structure of the Helvetic Nappes of the European Alps: Implications for Collisional Processes. Tectonics 39, 1-20.

Gomberg, J. and Cascadia 2007 and Beyond Working Group (2010) Slow-slip phenomena in Cascadia and beyond: a review. GSA Bull. 122, 963-978.

This article is protected by copyright. All rights reserved. 
Gorton, N.T., Walker, G. and D, B.S. (1997) Experimental analysis of the composite blue cathodoluminescence emission in quartz. Journal of Luminescence 72-74, 669-671.

Götze, J. and Kempe, U. (2008) A comparison of optical microscope- and scanning electron microscope-based cathodoluminescence $(\mathrm{CL})$ imaging and spectroscopy applied to geosciences. Mineral. Mag. 72, 909-924.

Götze, J., Plötze, M. and Habermann, D. (2001) Origin, spectral characteristics and practical applications of the cathodoluminescence $(\mathrm{CL})$ of quartz - a review. Mineralogy and Petrology 71, 225250.

Hall, D.L. and Sterner, S.M. (1993) Preferential water loss from synthetic fluid inclusions. Contrib. Mineral. Petrol. 114, 489-500.

Handy, M.R. and Brun, J.P. (2004) Seismicity, structure and strength of the continental lithosphere. Earth Planet. Sci. lett. 223, 427-441.

Hara, H. and Kimura, K. (2008) Metamorphic cooling history of the Shimanto accretionary complex, Kyushu, southwest Japan: Implications for the timing of out-of-sequence thrusting. Island Arc 17, 546-559.

Herrington, R. and Wilkinson, J.J. (1993) Colloidal gold and silica in mesothermal vein systems. Geology 21, 539-542.

Hilgers, C. and Urai, J.L. (2005) On the arrangement of solid inclusions in fibrous veins and the role of the crack-seal mechanism. J. Struct. Geol. 27, 481-494.

Hyndman, R.D., Yamano, M. and Oleskevich, D.A. (1997) The seismogenic zone of subduction thrust faults. The Island Arc 6, 244-260.

Ide, S., Beroza, G.C., Shelly, D.R. and Uchide, T. (2007) A scaling law for slow earthquakes. Nature 447, doi:10.1038/nature05780.

Ihinger, P.D. and Zink, S.I. (2000) Determination of relative growth rates of natural quartz crystals. Nature 404, 865-869.

Jonsson, S., Segall, P., Pedersen, R. and Bjornsson, G. (2003) Post-earthquake ground movements correlated to pore-pressure transients. Nature 424, 179-183.

Jourdan, A.-L., Vennemann, T.W., Müllis, J., Ramseyer, K. and Spiers, C.J. (2009) Evidence of growth and sector zoning in hydrothermal quartz from Alpine veins. Eur. J. Mineral. 21, 219-231.

Kameda, J., Raimbourg, H., Kogure, T. and Kimura, G. (2011) Low-grade metamorphism around the down-dip limit of seismogenic subduction zones: Example from an ancient accretionary complex in the Shimanto Belt, Japan. Tectonophysics 502, 383-392.

Kitamura, Y. and Kimura, G. (2012) Dynamic role of tectonic mélange during interseismic process of plate boundary mega earthquakes. Tectonophysics 568-569, 39-52.

Kondo, H., Kimura, G., Masago, H., Ohmori-Ikehara, K., Kitamura, Y., Ikesawa, E., Sakaguchi, A., Yamaguchi, A. and Okamoto, S. (2005) Deformation and fluid flow of a major out-of-sequence thrust located at seismogenic depth in an accretionary complex: Nobeoka Thrust in the Shimanto Belt, Kyushu, Japan. Tectonics 24, 1-16.

Lahfid, A., Beyssac, O., Deville, E., Negro, F., Chopin, C. and Goffé, B. (2010) Evolution of the Raman spectrum of carbonaceous material in low-grade metasediments of the Glarus Alps (Switzerland). Terra Nova 22, 354-360.

Lehmann, K., Berger, A., Gotte, T., Ramseyer, K. and Wiedenbeck, M. (2009) Growth related zonations in authigenic and hydrothermal quartz characterized by SIMS-, EPMA-, SEM-CL- and SEMCC-imaging. Mineral. Mag. 73, 633-643.

Mackenzie, J.S., Taguchi, S. and Itaya, T. (1989) Geochemical study of the greenstones of the Cretaceous and Paleogene Shimanto accretionary complex in eastern Kyushu: Implications for origin and mode of emplacement. J. Min. Petr. Econ. Geol. 84, 278-292.

Merinero, R., Lunar, R., Somoza, L., Diaz-del-Rio, V. and Martinez-Frias, J. (2009) Nucleation, growth and oxidation of framboidal pyrite associated with hydrocarbon-derived submarine chimneys:

lessons learned from the Gulf of Cadiz. Eur. J. Mineral. 21, 947-961.

Mookherjee, M., Keppler, H. and Manning, C.E. (2014) Aluminum speciation in aqueous fluids at deep crustal pressure and temperature. Geochim. Cosmochim. Ac. 133, 128-141.

This article is protected by copyright. All rights reserved. 
Moore, G.W. (1969a) New formations on Kodiak and adjacent islands, Alaska. U.S. Geological Survey Bulletin 1274-A, A27-A35.

Moore, J.C. (1969b) Cretaceous continental margin sedimentation, Southwestern Alaska. GSA Bull. 84, 595-614.

Moore, J.C. and Wheeler, R.L. (1978) Structural fabric of a mélange, Kodiak Islands, Alaska. Am. J. Sci. 278, 739-765.

Moreno, M., Haberland, C., Oncken, O., Rietbrock, A., Angiboust, S. and Heidbach, O. (2014) Locking of the Chile subduction zone controlled by fluid pressure before the 2010 earthquake. Nature Geoscience 7, 292-296.

Morey, G.W., Fournier, R.O. and Rowe, J.J. (1962) The solubility of quartz in water in the temperature interval from $25^{\circ}$ to $300^{\circ} \mathrm{C}$. Geochimica et Cosmochimica Acta 26, 1029-1043.

Muir-Wood, R. and King, G.C.P. (1993) Hydrological signatures of earthquake strain. J. Geophys. Res. 98, 22,035-022,068.

Mukoyoshi, H., Hirono, T., Hara, H., Sekine, K., Tsuchiya, N., Sakaguchi, A. and Soh, W. (2009) Style of fluid flow and deformation in and around an ancient out-of-sequence thrust: An example from the Nobeoka Tectonic Line in the Shimanto accretionary complex, southwest Japan. Island Arc 18, 333351.

Müller, A. and Koch-Müller, M. (2009) Hydrogen speciation and trace element contents of igneous, hydrothermal and metamorphic quartz from Norway. Mineral. Mag. 73, 569-583.

Müller, A., Wiedenbeck, M., Van den Kerkhof, A.M., Kronz, A. and Simon, K. (2003) Trace elements in quartz - a combined electron microprobe, secondary ion mass spectrometry, laser-ablation ICP-MS, and cathodoluminescence study. Eur. J. Mineral. 15, 747-763.

Mullis, J. (1979) The system methane-water as a geological thermometer and barometer from the external part of the Central Alps. Bull. Minéral. 102.

Mullis, J. (1987) Fluid inclusion studies during very low-grade metamorphism, in: Frey, M. (Ed.), Low temperature metamorphism. Backie, Glasgow, pp. 162-199.

Mullis, J. (1988) Rapid subsidence and upthrusting in the Northern Apennines, deduced by fluid inclusion studies in quartz crystals from Porretta Terme. Schweiz. Miner. Petrog. Mitt. 68, 157-170.

Murata, A. (1991) Duplex structures of the Uchinohae Formation in the Shimanto Terrane, Kyushu, Southwest Japan. J. Geol. Soc. Jap. 97, 39-52.

Murata, A. (1996) Nappe structures of the Shimanto terrane of the Mikado-Osuzuyama area in East Kyushu. Natural Science Research, Faculty of Integrated Arts and Sciences, The University of Tokushima 9, 49-61 (in japanese with english abstract).

Murata, A. (1997) Geological map of Miyazaki prefecture, 1:200,000. Miyazaki Prefectural Government.

Murata, A. (1998) Duplexes and low-angle nappe structures of the Shimanto terrane, southwest Japan. Memoir of Geological Society of Japan 50, 147-158 (in japanese with english abstract). Murata, A. (1999) Low-angle nappe structures of the Shimanto terrane in Kyushu and Shikoku, southwest Japan. J. Struct. Geol. Jpn. 43, 61-67 (in japanese with english abstract).

Nakashima, S. (1995) Diffusivity of ions in pore water as a quantitative basis for rock deformation rate estimates. Tectonophysics 245, 185-203.

Nibourel, L., Berger, A., Egli, D., Luensdorf, N.K. and Herwegh, M. (2018) Large vertical displacements of a crystalline massif recorded by Raman thermometry. Geology 46, 879-882.

Nishiyama, N., Sumino, H. and Ujiie, K. (2020) Fluid overpressure in subduction plate boundary caused by mantle-derived fluids. Earth Planet. Sci. Lett. 538, 1-11.

Oleskevich, D.A., Hyndman, R.D. and Wang, K. (1999) The updip and downdip limits to great subduction earthquakes: Thermal and structural models of Cascadia, south Alaska, SW Japan, and Chile. J. Geoph. Res. 104, 14965-14991.

Onishi, C.T., Kimura, G., Hashimoto, Y., Ikehara-Ohmori, K. and Watanabe, T. (2001) Deformation history of tectonic melange and its relationship to the underplating process and relative plate motion: An example from the deeply buried Shimanto Belt, SW Japan. Tectonics 20, 376-393.

This article is protected by copyright. All rights reserved. 
Palazzin, G. (2016) Brittle-ductile transition in subduction zones: the role of quartz. University of Orléans, p. 188pp.

Palazzin, G., Raimbourg, H., Famin, V., Jolivet, L., Kusaba, Y. and Yamaguchi, A. (2016) Deformation processes at the down-dip limit of the seismogenic zone: The example of Shimanto accretionary complex. Tectonophysics 687, 28-43.

Perny, B., Eberhardt, P., Ramseyer, K., Mullis, J. and Pankrath, R. (1992) Microdistribution of Al, Li, and $\mathrm{Na}$ in $\alpha$ quartz. Possible causes and correlation with short-lived cathodoluminescence. Am. Mineralogist 77, 534-544.

Raimbourg, H., Augier, R., Famin, V., Gadenne, L., Palazzin, G., Yamaguchi, A. and Kimura, G. (2014a) Long-term evolution of an accretionary prism: the case study of the Shimanto Belt, Kyushu, Japan. Tectonics 33, 1-24.

Raimbourg, H., Famin, V., Palazzin, G., Mayoux, M., Jolivet, L., Ramboz, C. and Yamaguchi, A. (2018) Fluid properties and dynamics along the seismogenic plate interface. Geosphere: Subduction top to bottom 2 14, 1-23.

Raimbourg, H., Famin, V., Palazzin, G., Sakaguchi, A., Yamaguchi, A. and Augier, R. (2017a) Tertiary evolution of the Shimanto Belt (Japan): a large-scale collision in Early Miocene. Tectonics 36, 1-21. Raimbourg, H., Famin, V., Palazzin, G., Yamaguchi, A., Augier, R., Kitamura, Y. and Sakaguchi, A. (2019) Distributed deformation along the subduction plate interface: The role of tectonic mélanges. Lithos 334-335, 69-87.

Raimbourg, H., Thiéry, R., Vacelet, M., Famin, V., Ramboz, C., Boussafir, M., Disnar, J.-R. and Yamaguchi, A. (2017b) Organic matter cracking: a source of fluid overpressure in subducting sediments. Tectonophysics 721, 254-274.

Raimbourg, H., Thiery, R., Vacelet, M., Ramboz, C., Cluzel, N., Trong, E.L., Yamaguchi, A. and Kimura, G. (2014b) A new method of reconstituting the P-T conditions of fluid circulation in an accretionary prism (Shimanto, Japan) from microthermometry of methane-bearing aqueous inclusions. Geochim Cosmochim Ac 125, 96-109.

Raimbourg, H., Vacelet, M., Ramboz, C., Famin, V., Augier, R., Palazzin, G., Yamaguchi, A. and Kimura, G. (2015) Fluid circulation in the depths of accretionary prisms: an example of the Shimanto Belt, Kyushu, Japan. Tectonophysics 655, 161-176.

Ramsay, J.G. (1980) The crack-seal mechanism of rock deformation. Nature 284, 135-139.

Ramseyer, K. and Mullis, J. (1990) Factors influencing short-lived blue cathodoluminescencoef $\alpha$ quartz. Am. Mineral. 75, 791-800.

Robert, F., Boullier, A.M. and Firdaous, K. (1995) Gold-quartz veins in metamorphic terranes and their bearing on the role of fluids in faulting. J. Geophys. Res. 100, 12,861-812,879.

Rowe, C.D., Meneghini, F. and Moore, J.C. (2009) Fluid-rich damage zone of an ancient out-ofsequence thrust, Kodiak Islands, Alaska. Tectonics 28, 1-20.

Rusk, B.G., Lowers, H.A. and Reed, M.H. (2008) Trace elements in hydrothermal quartz: Relationships to cathodoluminescent textures and insights into vein formation. Geology 36, 547-550.

Saffer, D. and Tobin, H.J. (2011) Hydrogeology and mechanics of subduction zone forearcs: Fluid flow and pore pressure. Ann. Rev. Earth Planet. Sci. 39, 157-186.

Sakai, A. and Kanmera, K. (1981) Stratigraphy of the Shimanto terrane and the tectono-stratigraphic setting of the greenstones of the northern part of Miyazaki prefecture, Kyushu. Sci. Rep. Dep. Geol. Kyushu Univ. 14, 31-48.

Sample, J.C. and Fisher, D.M. (1986) Duplex accretion and underplating in an ancient accretionary complex, Kodiak Islands, Alaska. Geology 14, 160-163.

Sample, J.C. and Moore, J.C. (1987) Structural style and kinematics of an underplated slate belt, Kodiak and adjacent islands, Alaska. GSA Bull. 99, 7-20.

Schwartz, S. and Rokosky, J.M. (2007) Slow slip events and seismic tremor at circum-Pacific subduction zones. Rev. Geophys. 45, 1-Sibson, R.H. (1994) Crustal stress, faulting and fluid flow. Special Publications of the Geological society of London 78, 69-84.

This article is protected by copyright. All rights reserved. 
Sterner, S.M. and Bodnar, R.J. (1989) Synthetic fluid inclusions - VII. Re-equilibration of fluid inclusions in quartz during laboratory-simulated metamorphic burial and uplift. J. Metamorphic Geol. 7, 243-260.

Sterner, S.M., Hall, D.L. and Keppler, H. (1995) Compositional re-equilibration of fluid inclusions in quartz. Contrib. Mineral. Petrol. 119, 1-15.

Stipp, M., Stünitz, H., Heilbronner, R. and Schmid, S.M. (2002) The eastern Tonale fault zone: a "natural" laboratory for crystal plastic deformation of quartz over a temperature range from $250^{\circ} \mathrm{C}$ to $700^{\circ} \mathrm{C}$. J. Struct. Geol. 24, 1861-1884.

Taira, A. (1981) The Shimanto Belt of southwest Japan and arc-trench sedimentary tectonics. Recent Progress of Natural Sciences in Japan 6, 147-162.

Taira, A., Katto, J., Tashiro, M., Okamura, M. and Kodama, K. (1988) The Shimanto Belt in Shikoku, Japan-Evolution of Cretaceous to Miocene accretionary prism. Modern Geology 12, 5-46.

Taira, A., Tashiro, M., Okamura, M. and Katto, J. (1980) The geology of the Shimanto Belt in Kochi prefecture, Shikoku, in: Taira, A., Tashiro, H. (Eds.), Geology and paleontology of the Shimanto Belt. Rinyo Kosaikai Press, Kochi, pp. 319-389.

Tanaka, K. and Nozawa, T. (1977) Geology and mineral resources of Japan. Geological Survey of Japan.

Toriumi, M. and Teruya, J. (1988) Tectono-metamorphism of the Shimanto Belt. Modern Geology 12, 303-324.

Ujiie, K., Saishu, H., Fagereng, A., Nishiyama, N., Otsubo, M., Masuyama, H. and Kagi, H. (2018) An explanation of episodic tremor and slow slip constrained by crack-seal veins and viscous shear in subduction mélange. Geophys. Res. Lett. 45, 5371-5379.

Van Achterbergh, E., Ryan, C.G. and Griffin, W.L. (2001) GLITTER on-line interactive data reduction for the LA-ICPMS microprobe. Macquarie Research Ltd, Sydney.

Vityk, M.O. and Bodnar, R.J. (1995) Do fluid inclusions in high-grade metamorphic terranes preserve peak metamorphic density during retrograde decompression? Am. Mineral. 80, 641-644.

Vityk, M.O., Bodnar, R.J. and Doukhan, J.C. (2000) Synthetic fluid inclusions. XV. TEM investigation of plastic flow associated with reequilibration of fluid inclusions in natural quartz. Contrib. Mineral. Petrol. 139, 285-297.

Vityk, M.O., Bodnar, R.J. and Schmidt, C.S. (1994) Fluid inclusions as tectonothermobarometers: Relation between pressure-temperature history and reequilibration morphology during crustal thickening. Geology 22, 731-734.

Vrojlik, P. (1987) Tectonically-driven fluid flow in the Kodiak accretionary complex, Alaska. Geology 15, 466-469.

Walther, J.V. and Orville, P.M. (1982) Volatile production and transport in regional metamorphism. Contrib. Mineral. Petrol. 79, 252-257.

Watt, G.R., Wright, P., Galloway, S. and McLean, C. (1997) Cathodoluminescence and trace element zoning in quartz phenocrysts and xenocrysts. Geochim. Cosmochim. Ac. 61, 4337-4348.

Weatherley, D.K. and Wenley, R.W. (2013) Flash vaporization during earthquakes evidenced by gold deposits. Nature Geoscience 6, 294-298.

Welsch, B., Faure, F., Famin, V., Baronnet, A., and Bachèlery, P. (2013) Dendritic crystallization: a single process for all the textures of olivine in basalts?: J. Petrol., v. 54, no. 3, p. 539-574.

Welsch, B., Hammer, J. and Hellebrand, E. (2014) Phosphorus zoning reveals dendritic architecture of olivine. Geology 42, 867-870.

Weatherley, D.K. and Wenley, R.W. (2013) Flash vaporization during earthquakes evidenced by gold deposits. Nature Geoscience 6, 294-298.

Wilkinson, J.J. and Johnston, J.D. (1996) Pressure fluctuations, phase separation, and gold precipitation during seismic fracture propagation. Geology 24, 395-398.

Yamaguchi, A., Cox, S.F., Kimura, G. and Okamoto, S. (2011) Dynamic changes in fluid redox state associated with episodic fault rupture along a megasplay fault in a subduction zone. Earth Planet. Sci. Lett. 302, 369-377.

This article is protected by copyright. All rights reserved. 
Yamaguchi, A., Ujiie, K., Nakai, S. and Kimura, G. (2012) Sources and physicochemical characteristics of fluids along a subduction-zone megathrust: A geochemical approach using syn-tectonic mineral veins in the Mugi mélange, Shimanto accretionary complex. Geochem. Geophys. Geosyst. 13, 1-22.

This article is protected by copyright. All rights reserved. 

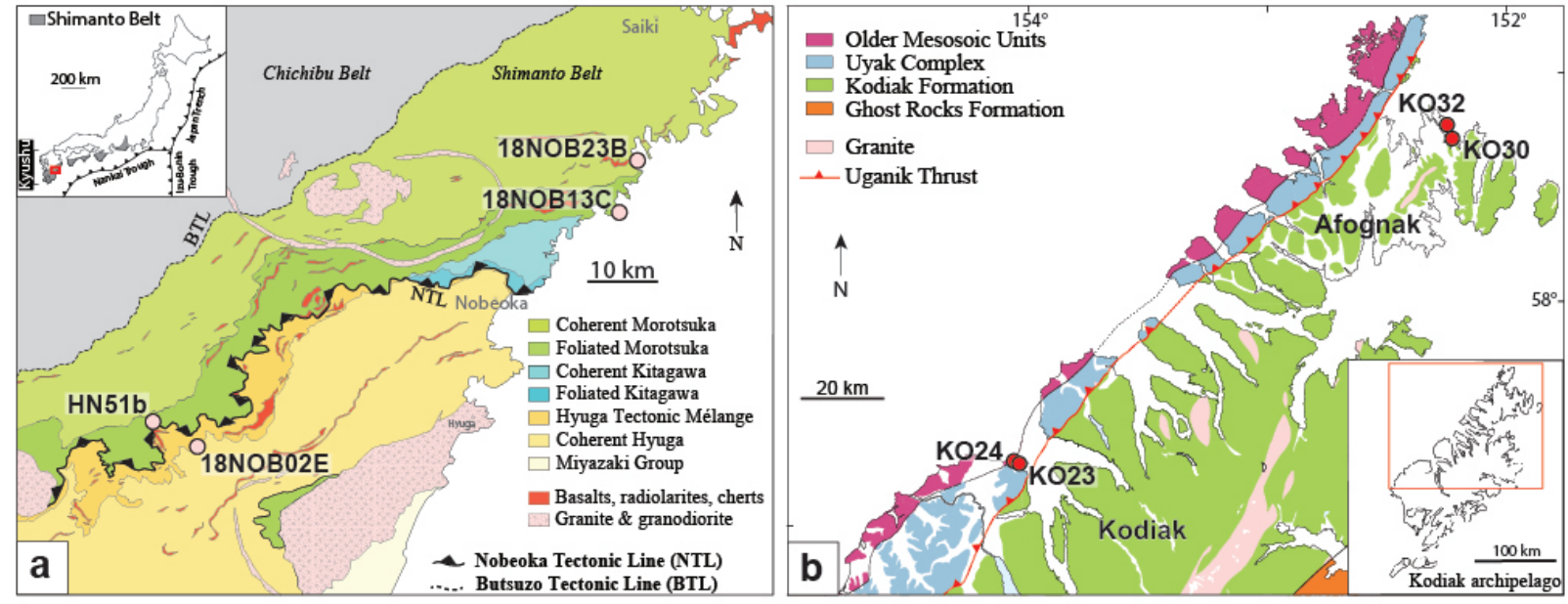

This article is protected by copyright. All rights reserved. 

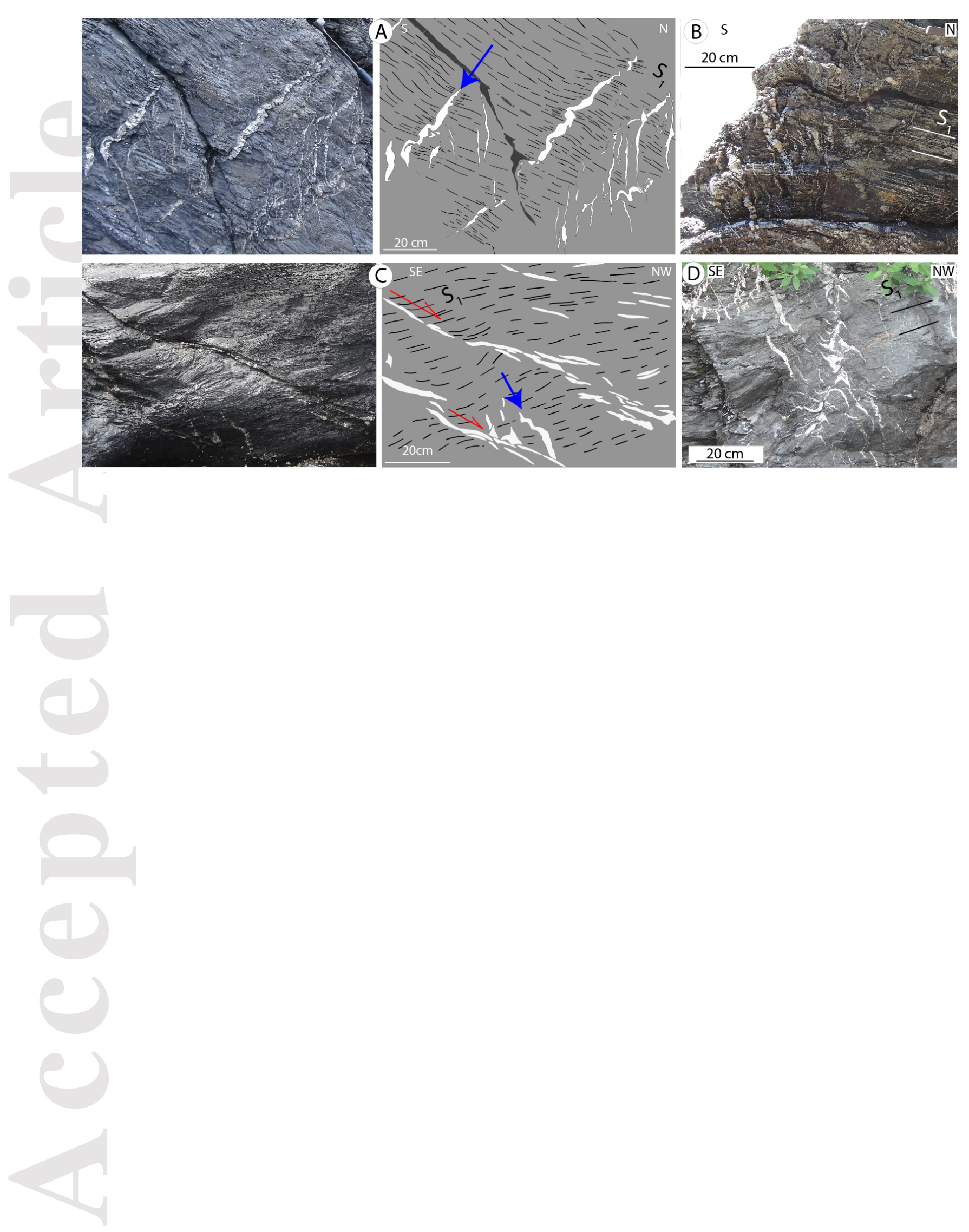

This article is protected by copyright. All rights reserved. 


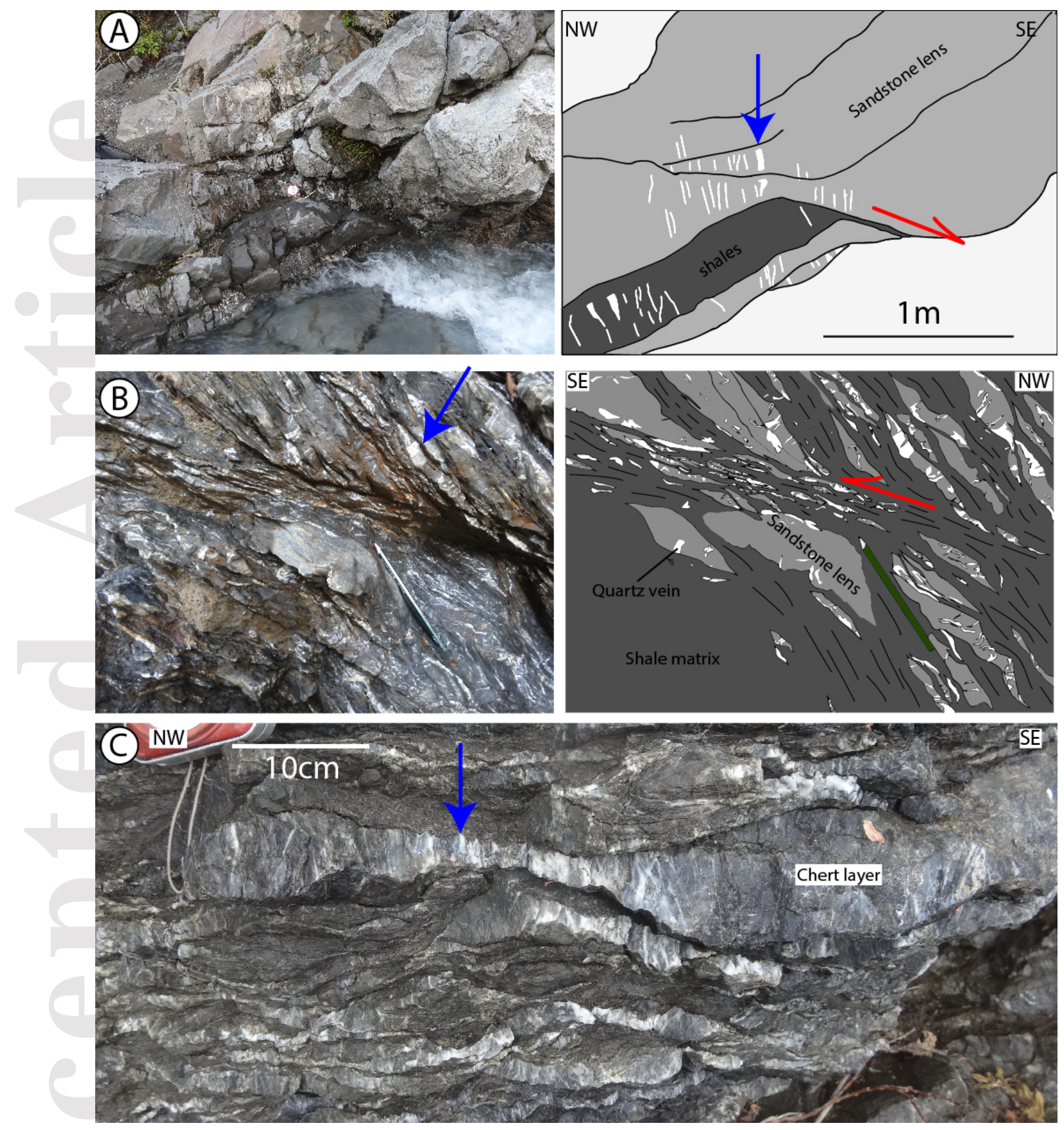

This article is protected by copyright. All rights reserved. 


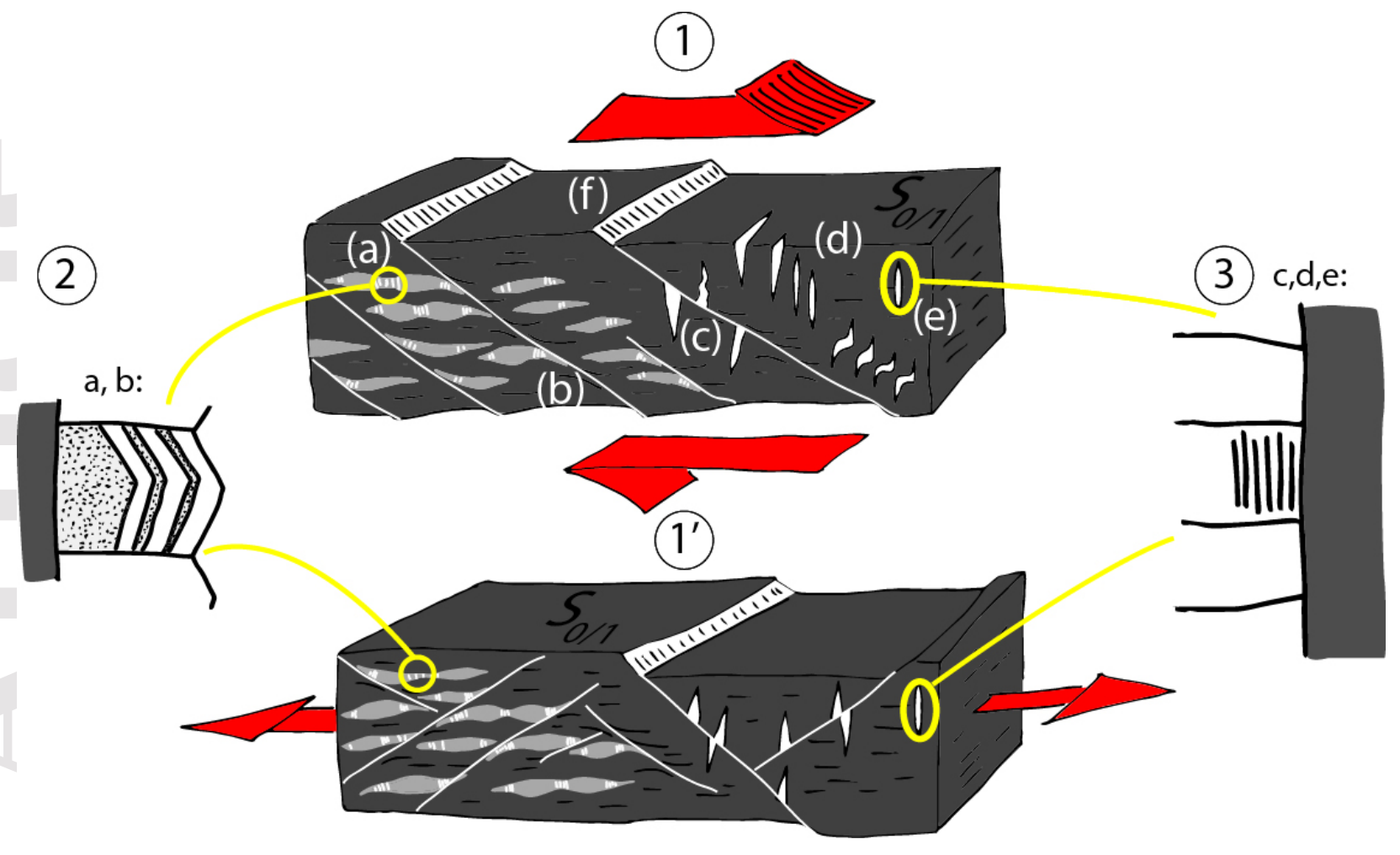

This article is protected by copyright. All rights reserved. 


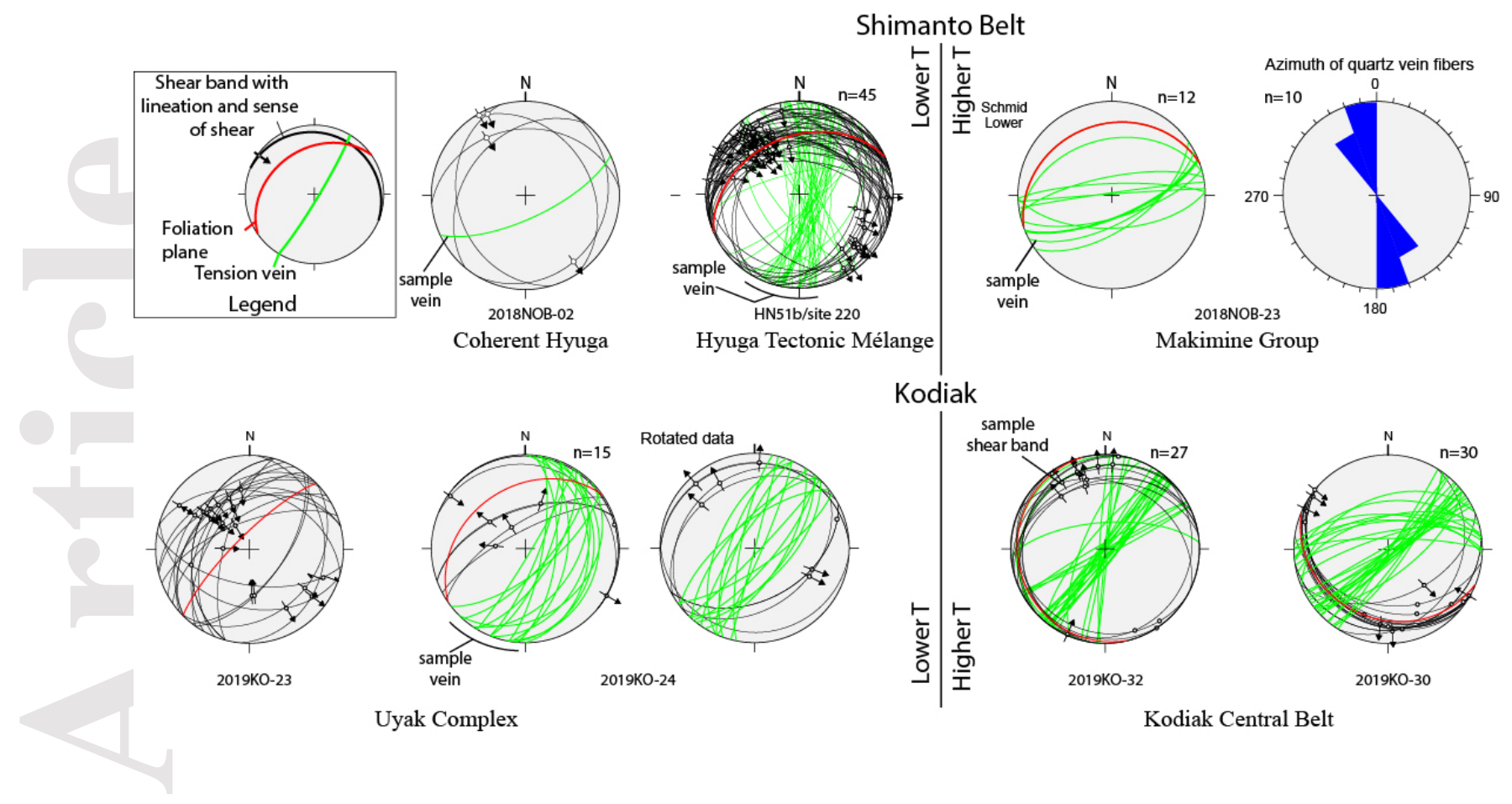

This article is protected by copyright. All rights reserved. 


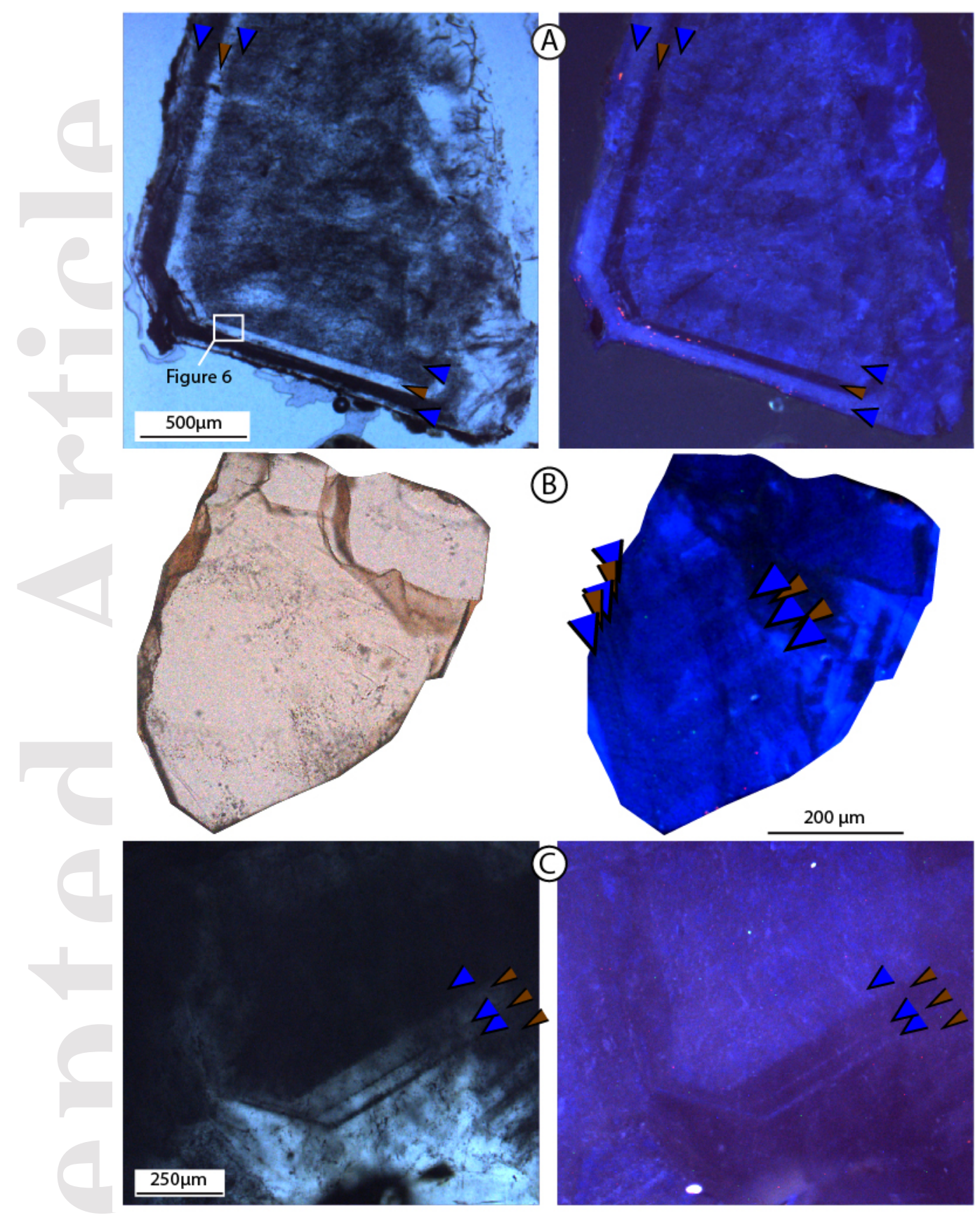

This article is protected by copyright. All rights reserved. 

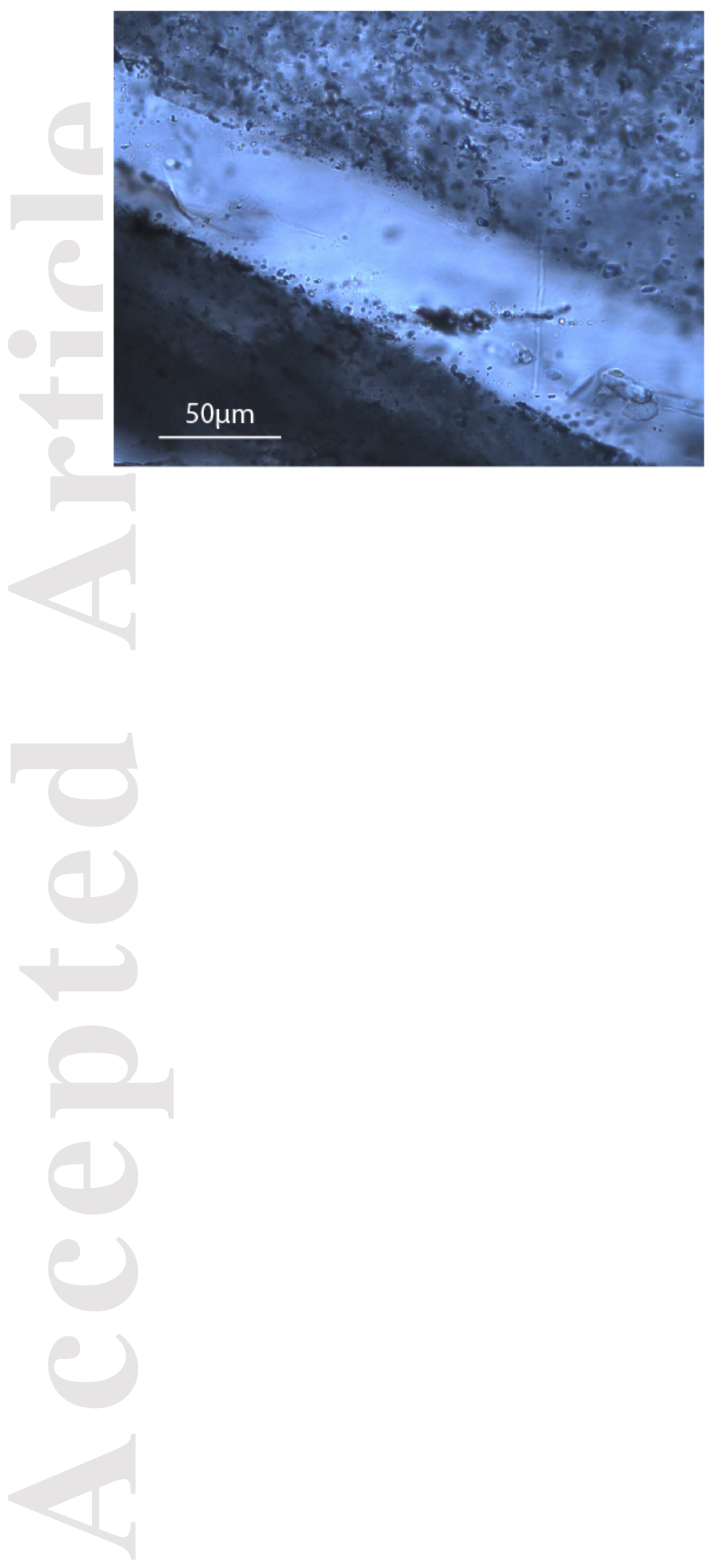

This article is protected by copyright. All rights reserved. 

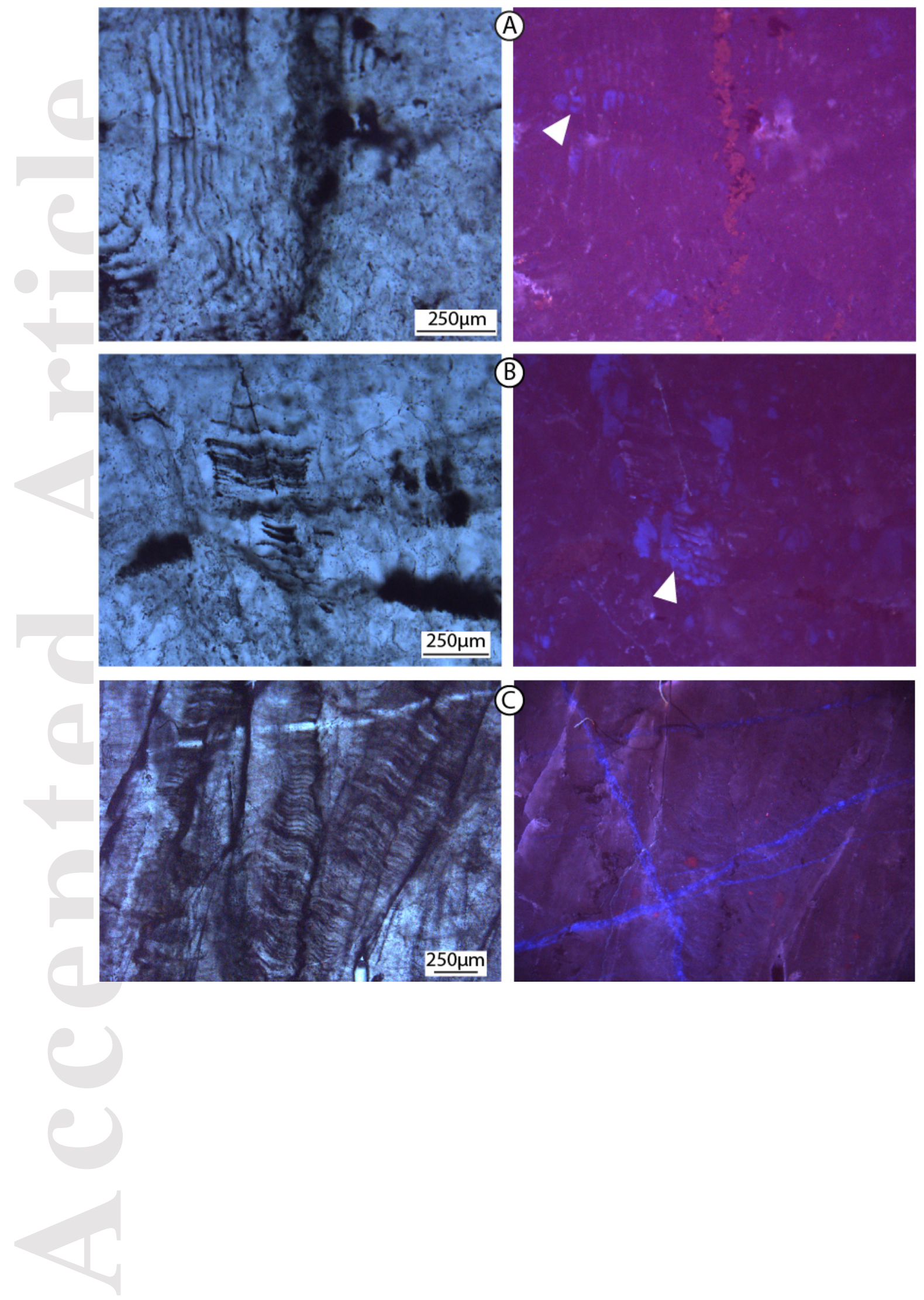

This article is protected by copyright. All rights reserved. 

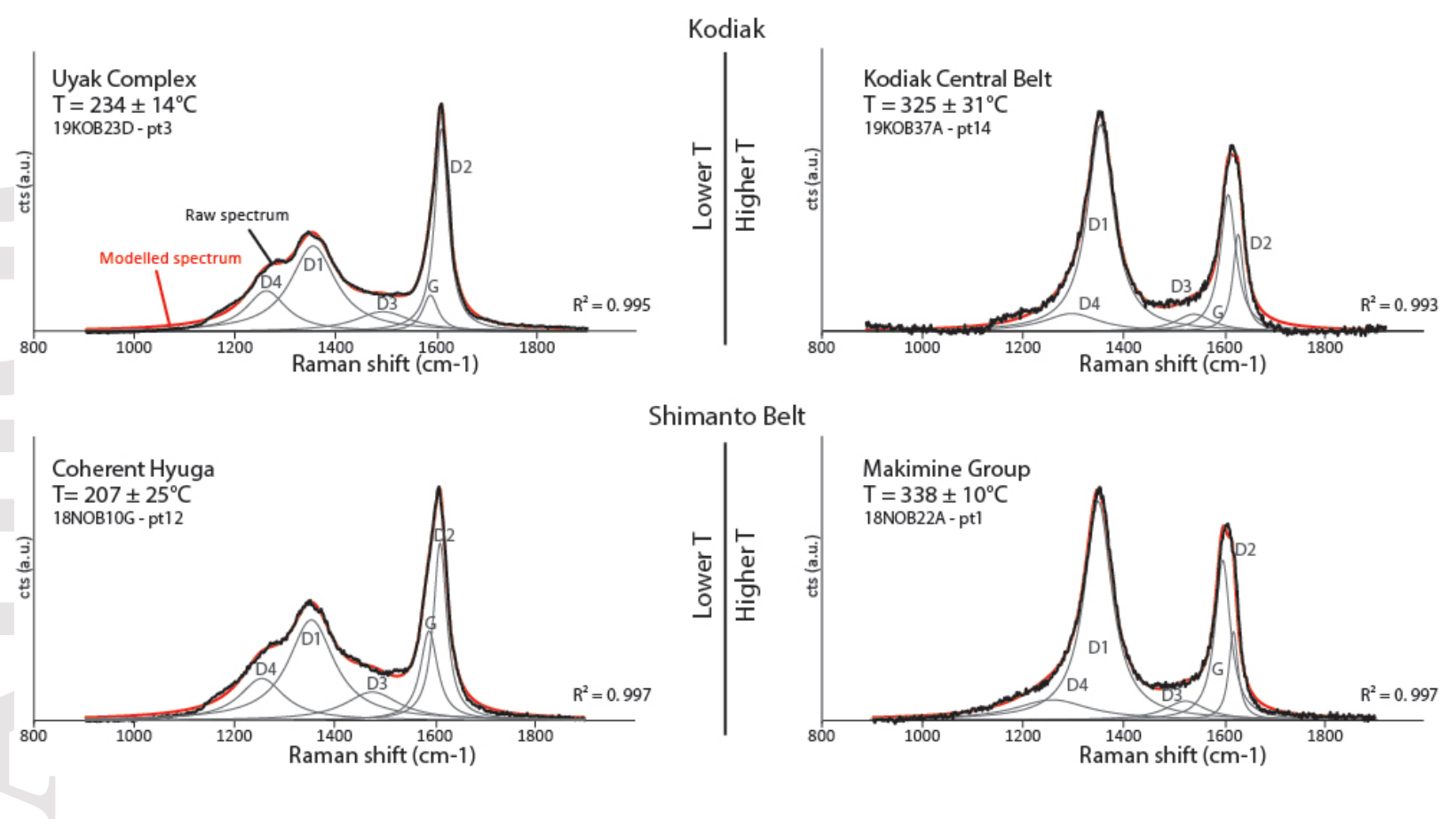

This article is protected by copyright. All rights reserved. 

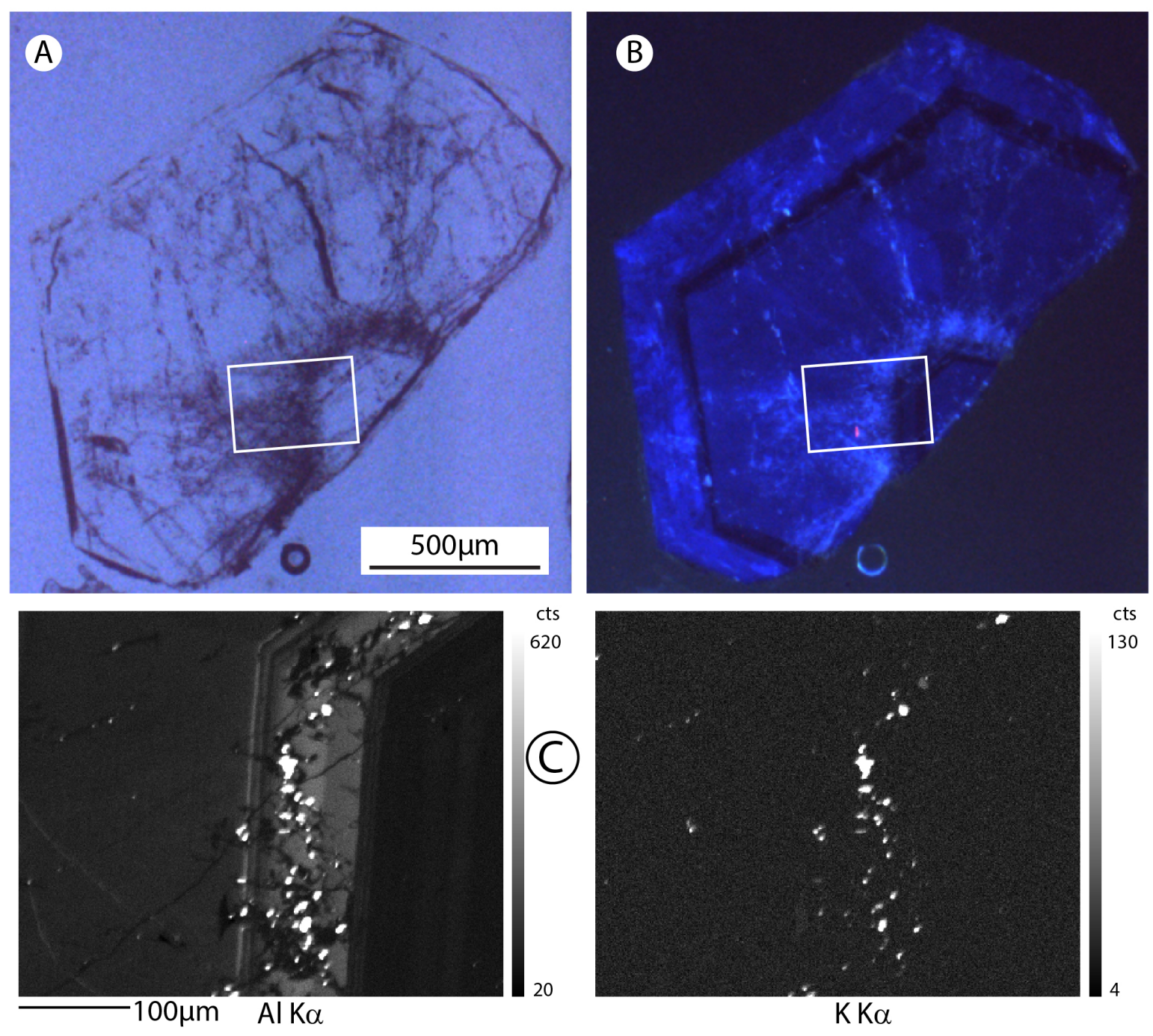

This article is protected by copyright. All rights reserved. 

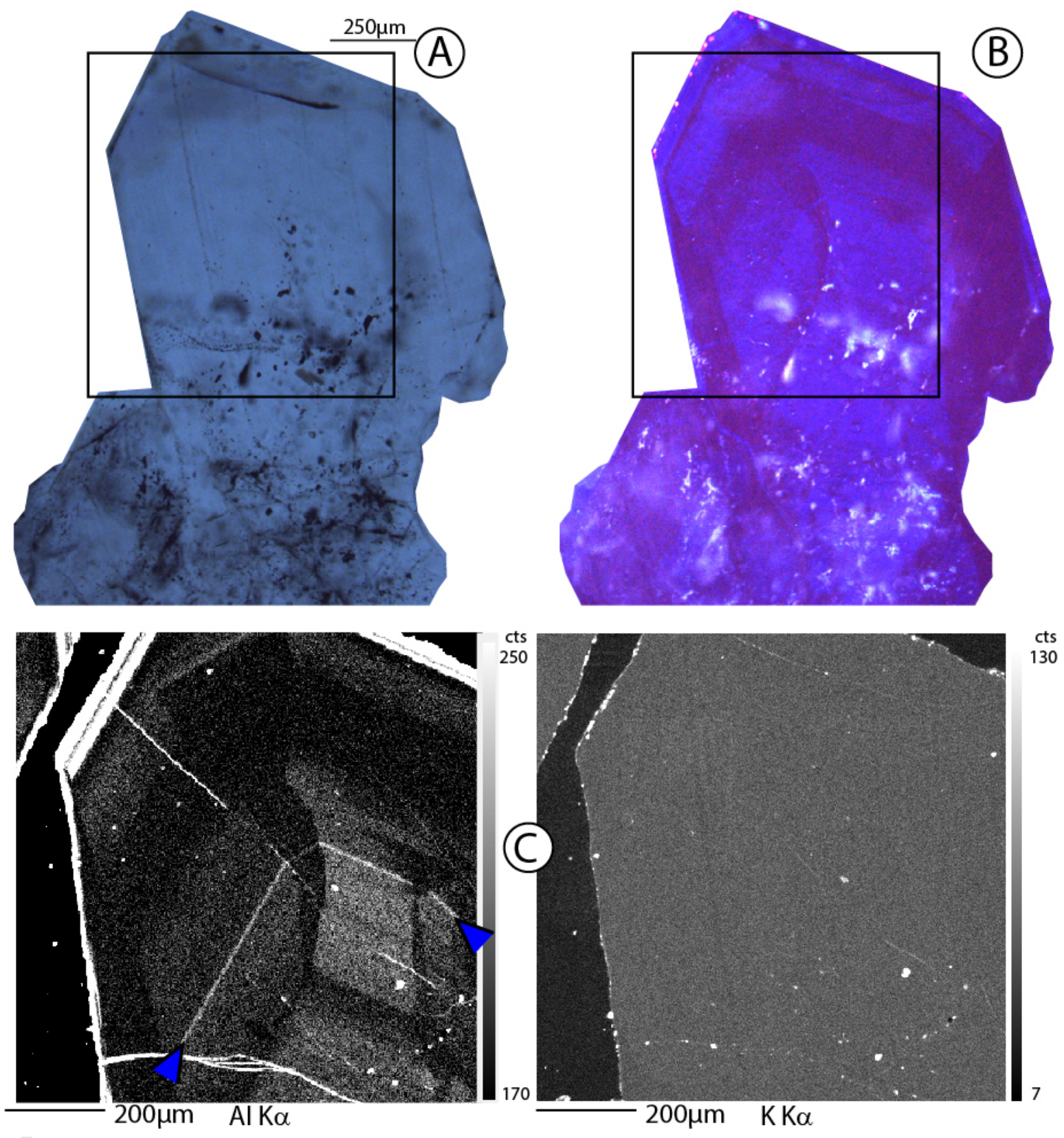

This article is protected by copyright. All rights reserved. 


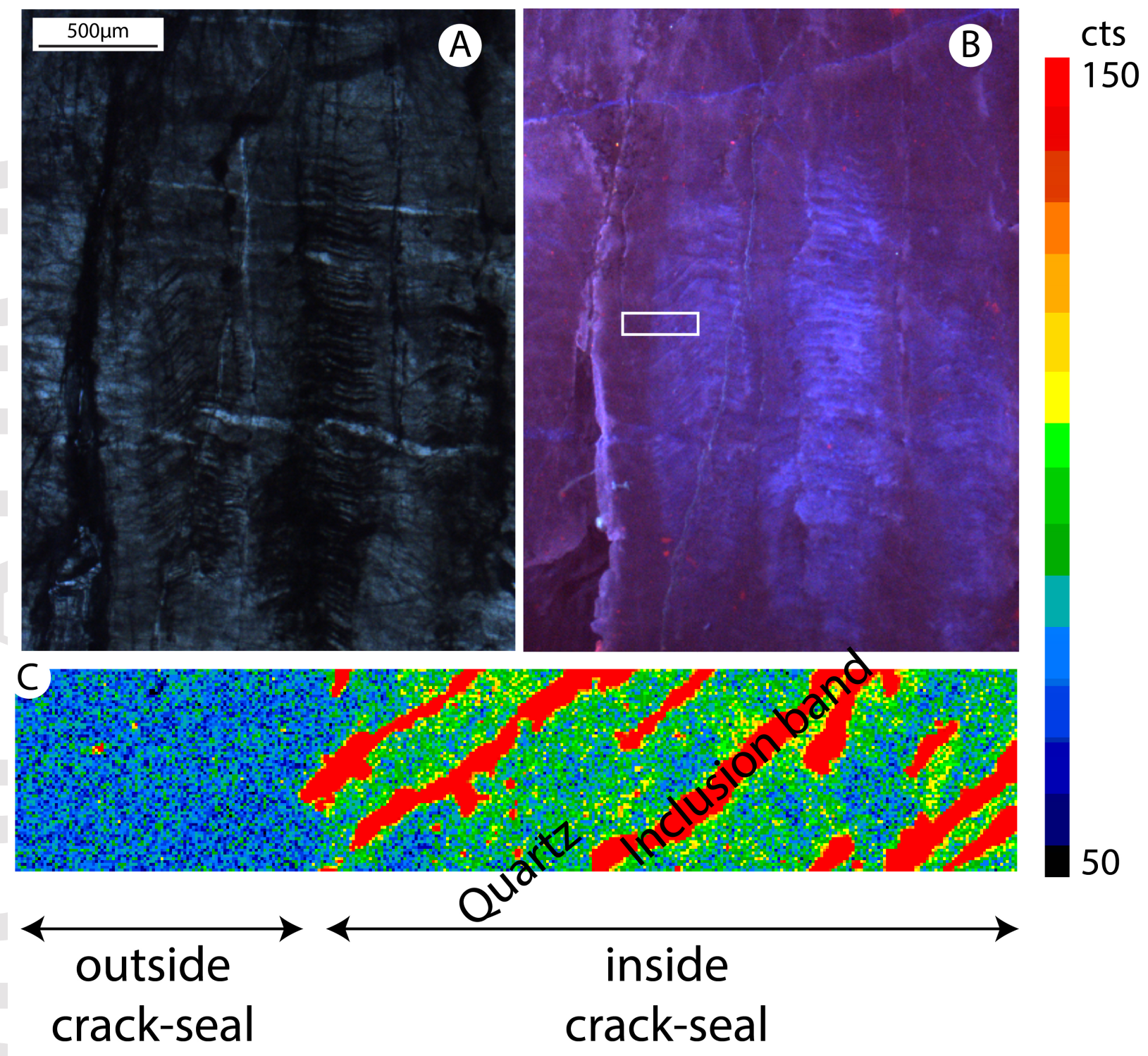

This article is protected by copyright. All rights reserved. 


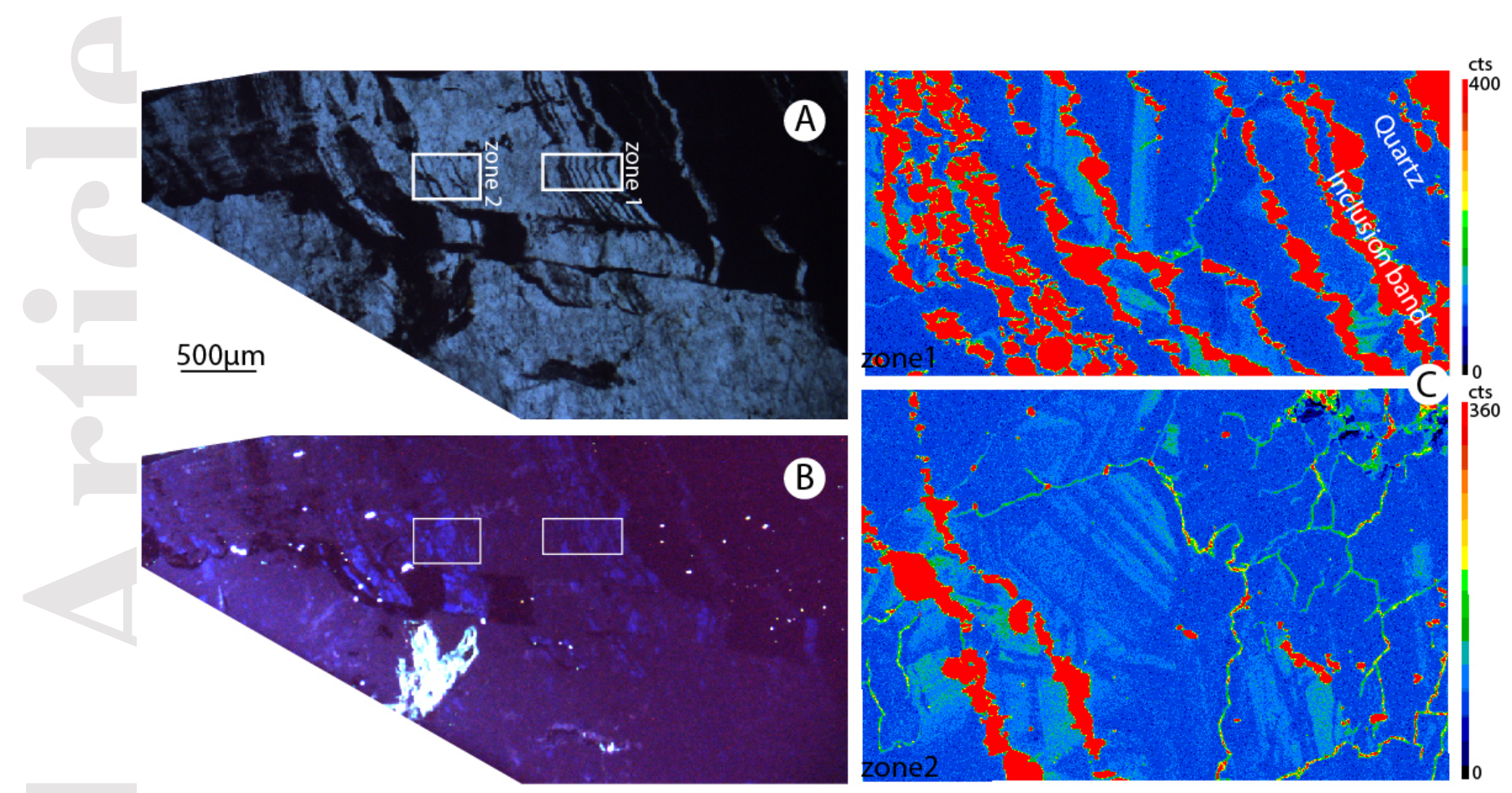

This article is protected by copyright. All rights reserved. 

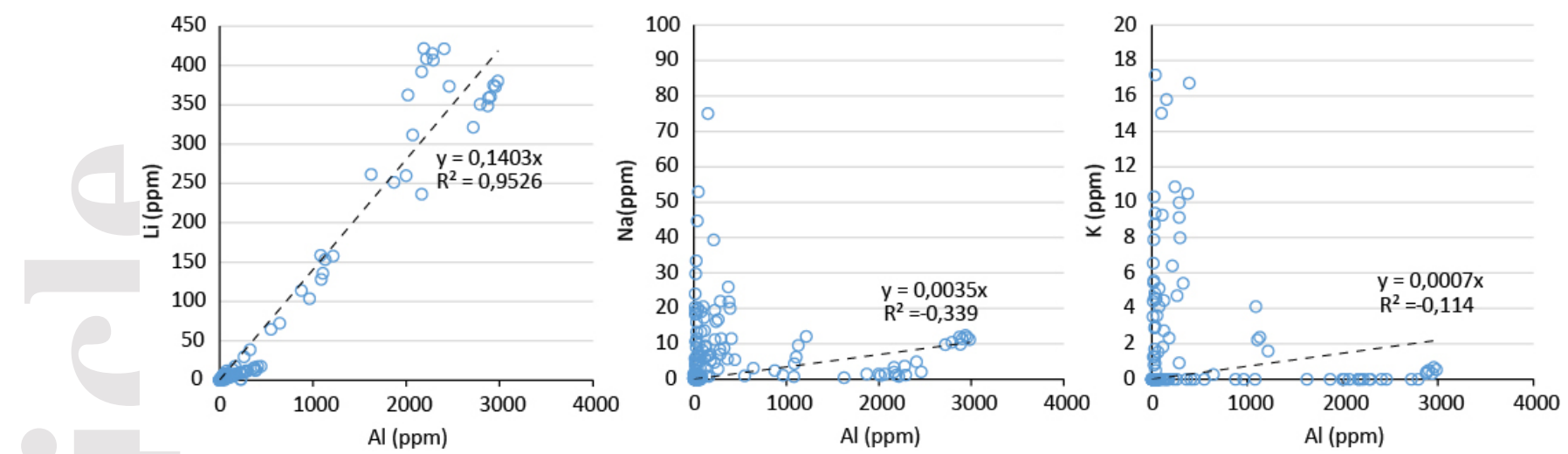

This article is protected by copyright. All rights reserved. 


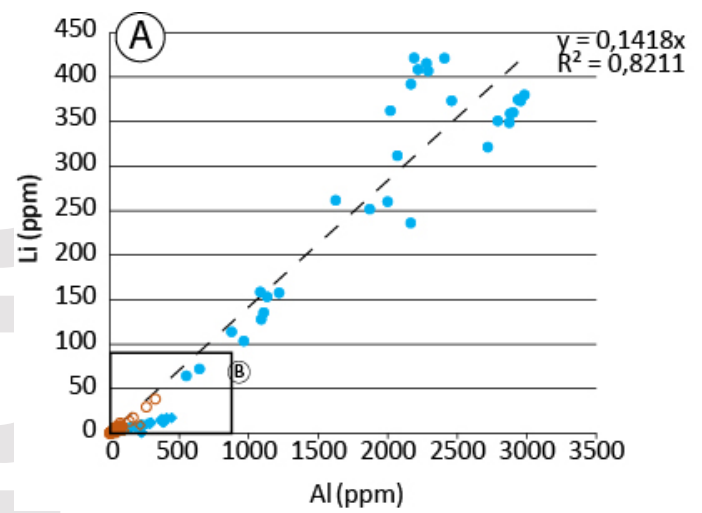

Kodiak:

- CL-blue quartz

- CL-brown quartz

Shimanto:

- CL-blue quartz

- CL-brown quartz

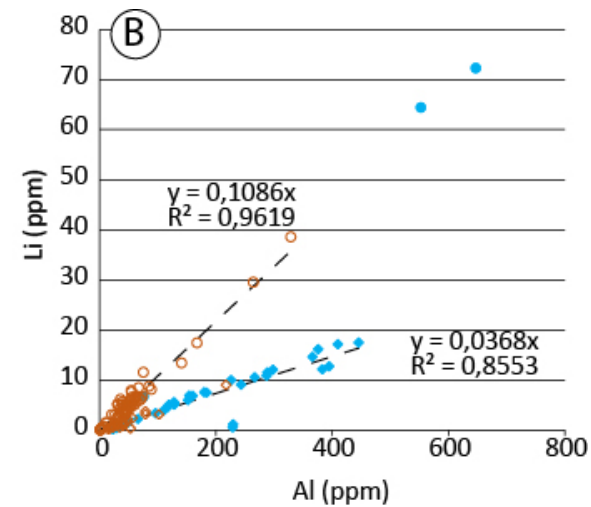

This article is protected by copyright. All rights reserved. 

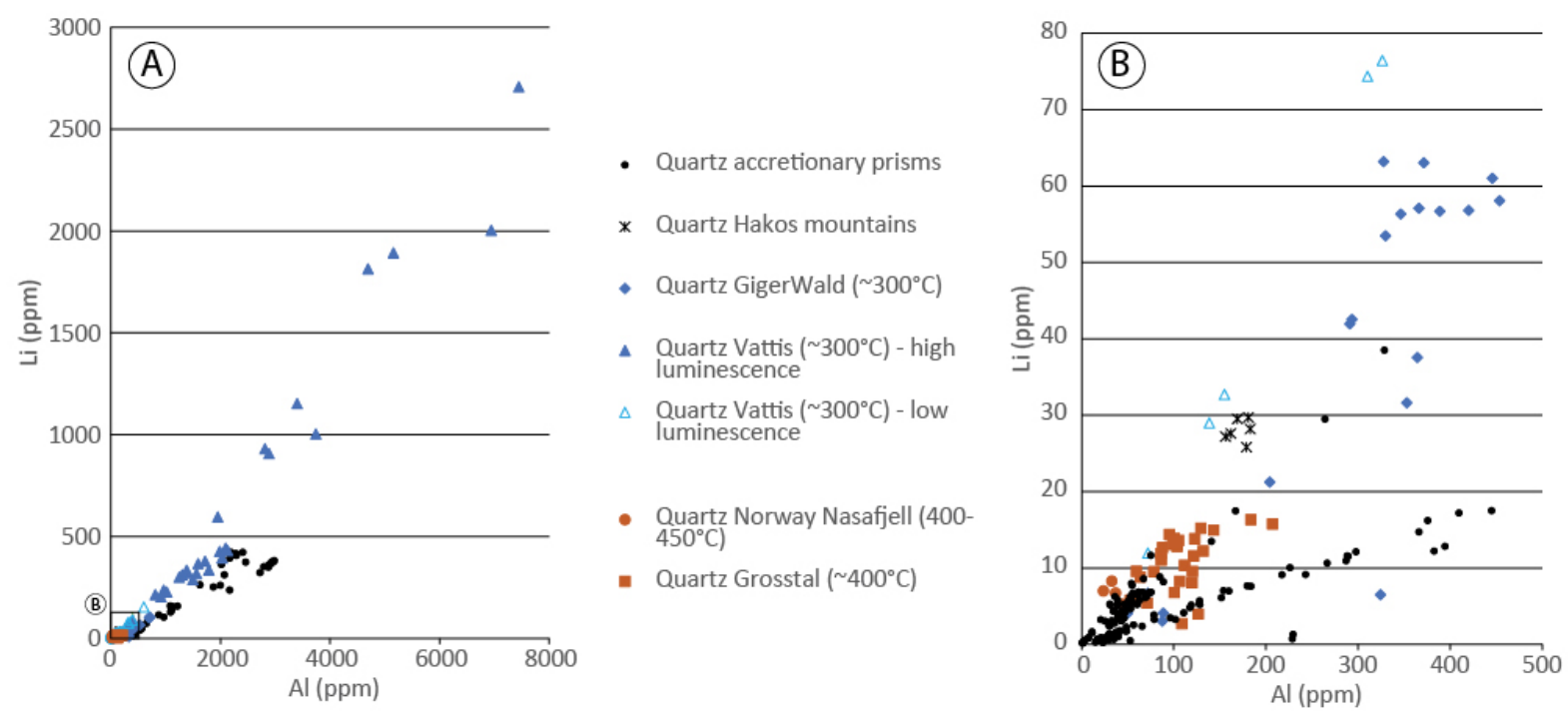

This article is protected by copyright. All rights reserved. 


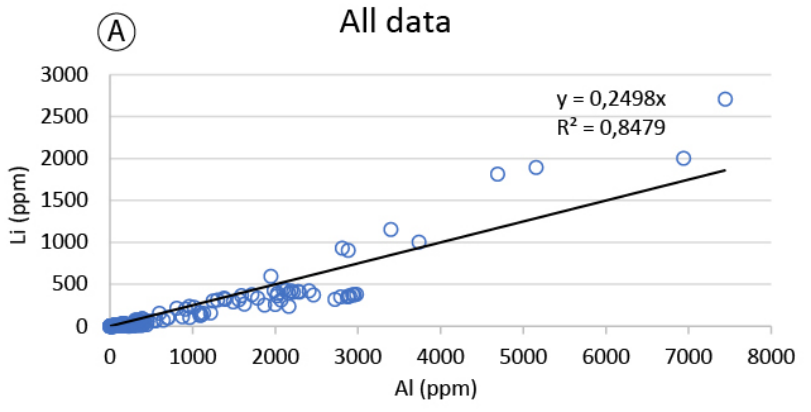

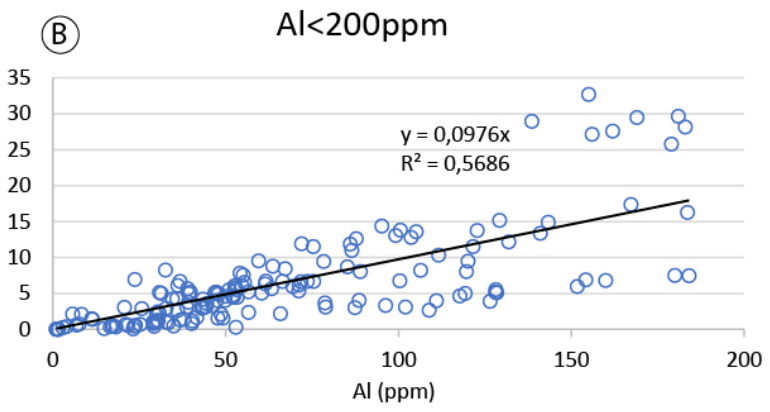

This article is protected by copyright. All rights reserved. 


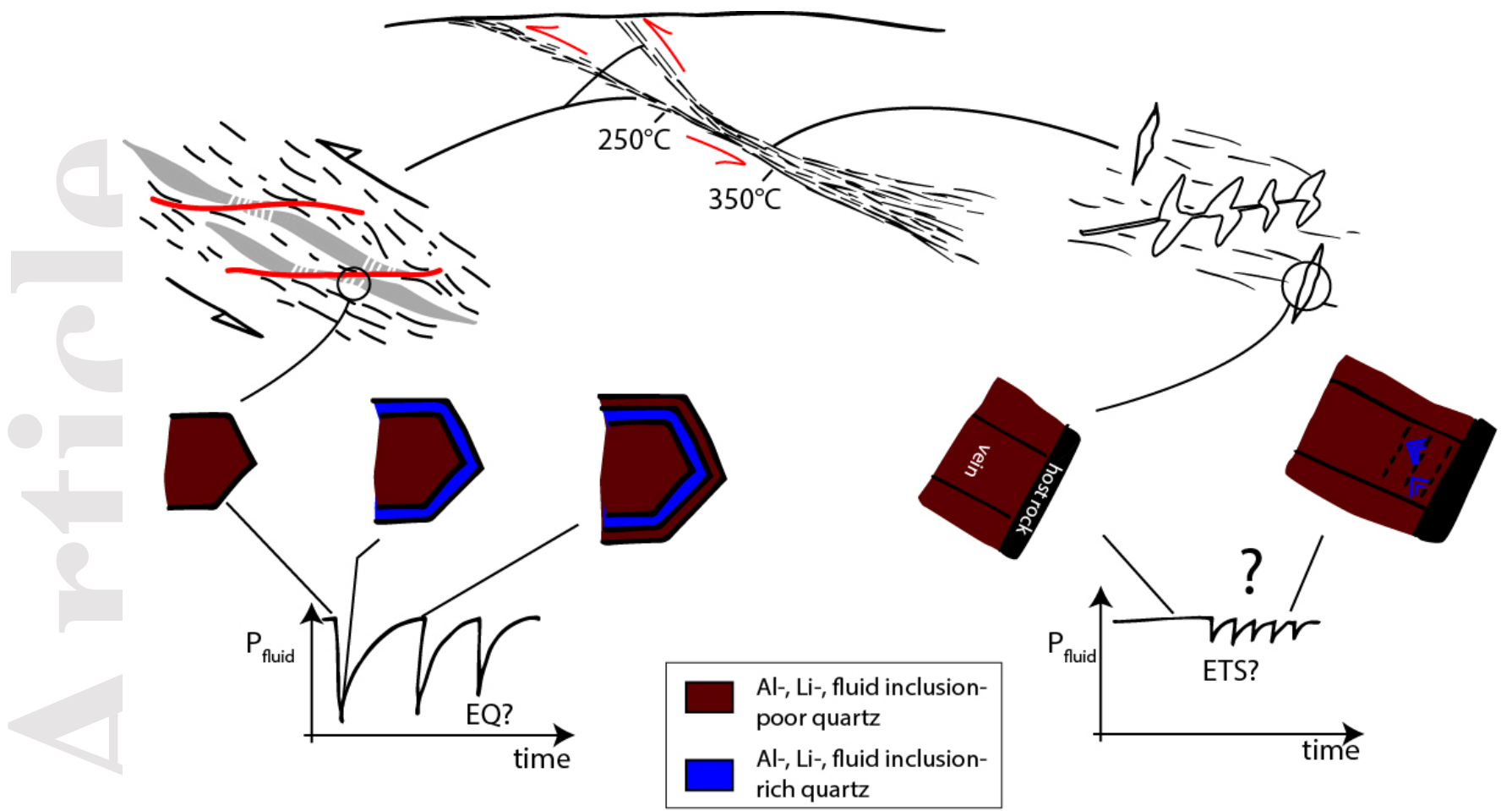

Growth rim microstructures

Crack-seal microstructures

This article is protected by copyright. All rights reserved. 


\begin{tabular}{|c|c|c|c|c|c|c|c|c|c|c|}
\hline Geological domain & Geological Unit & Sample & Structures & Microstructure & Longitude & Latitude & $\begin{array}{c}\text { RSCM: } \\
\text { number of } \\
\text { analyses } \\
\end{array}$ & $\begin{array}{c}\mathrm{RA} 1=(\mathrm{D} 1+\mathrm{D} 4) / \\
(\mathrm{D} 1+\mathrm{D} 2+\mathrm{D} 3+\mathrm{D} 4+\mathrm{G})\end{array}$ & $\begin{array}{c}\text { Veining mean } \\
\text { temperature } \\
\left({ }^{\circ} \mathrm{C}\right) \\
\end{array}$ & $\begin{array}{c}\text { Temperature } \\
\text { standard deviation }\left({ }^{\circ} \mathrm{C}\right)\end{array}$ \\
\hline \multirow{2}{*}{$\begin{array}{c}\text { Kodiak Accretion } \\
\text { Complex, Alaska, } \\
\text { USA }\end{array}$} & \multirow{2}{*}{$\begin{array}{l}\text { Uyak Complex } \\
\text { Kodiak Central } \\
\text { Belt }\end{array}$} & $2019 \mathrm{KO} 24 \mathrm{~A}$ & $\begin{array}{l}\text { Tension crack in chert lenses } \\
\text { associated with shear band }\end{array}$ & $\begin{array}{l}\text { CL-blue and CL- } \\
\text { brown growth rims }\end{array}$ & -154.02900 & 57.65183 & 12 & 0.57 & 234 & 14 \\
\hline & & 2019КО32А & $\begin{array}{l}\text { Quartz veins associated with } \\
\text { shear band }\end{array}$ & Crack-seal & -152.24506 & 58.38931 & 15 & 0.64 & 325 & 31 \\
\hline \multirow{3}{*}{$\begin{array}{l}\text { Shimanto Belt, } \\
\text { Kyushu, Japan }\end{array}$} & $\begin{array}{l}\text { Coherent Hyuga } \\
\text { Formation }\end{array}$ & 18NOB02E & $\begin{array}{c}\text { Tension crack in sandstone } \\
\text { beds associated with shear } \\
\text { band }\end{array}$ & $\begin{array}{l}\text { CL-blue and CL- } \\
\text { brown growth rims }\end{array}$ & 131.29864 & 32.38600 & 11 & 0.56 & 207 & 25 \\
\hline & $\begin{array}{l}\text { Hyuga Tectonic } \\
\text { Mélange }\end{array}$ & HN51b & $\begin{array}{c}\text { Tension crack in sandstone } \\
\text { lens associated with shear } \\
\text { band }\end{array}$ & $\begin{array}{c}\text { CL-blue and CL- } \\
\text { brown growth rims }\end{array}$ & 131.24250 & 32.41610 & 12 & 0.57 & 259 & 14 \\
\hline & Makimine Group & 18NOB23B & $\begin{array}{l}\text { Quartz veins associated with } \\
\text { lineated quartz vein at low- } \\
\text { angle to schistosity }\end{array}$ & Crack-seal & 131.87875 & 32.76136 & 32 & 0.65 & 338 & 10 \\
\hline $\begin{array}{l}\text { Helminthoides } \\
\text { Flysch, Alps, } \\
\text { France }\end{array}$ & Basal Complex & $\mathrm{FH} 2$ & $\begin{array}{l}\text { Tension crack in isoclinally } \\
\text { folded sandstone bed }\end{array}$ & $\begin{array}{l}\text { CL-blue and CL- } \\
\text { brown growth rims }\end{array}$ & 6.72594 & 44.52633 & 11 & 0.61 & $<292$ & 26 \\
\hline
\end{tabular}


Ech HN51b

Les T Raman viennent de 18NOB05 (mission 2018 avec Benjamin)

0.57421307

0.57828269

0.58178298

0.59504982

0.57613433

0.56984244

0.55372589

0.5713058

0.5798234

0.56739233

0.56259389

0.56385752

0.57283368

\begin{tabular}{|c|c|c|c|}
\hline RSCM: & $\mathrm{RA} 1=(\mathrm{D} 1+$ & Veining & Temperature \\
number of & $\mathrm{D} 4) /$ & mean & standard \\
analyses & $(\mathrm{D} 1+\mathrm{D} 2+$ & temperature & deviation $\left({ }^{\circ} \mathrm{C}\right)$ \\
& $\mathrm{D} 3+\mathrm{D} 4+\mathrm{G})$ & $\left({ }^{\circ} \mathrm{C}\right)$ & \\
\hline
\end{tabular}

\begin{tabular}{|c|c|c|c|c|c|c|c|c|c|}
\hline $\begin{array}{c}\text { Kodiak Central } \\
\text { Belt }\end{array}$ & 2019KО32A & $\begin{array}{c}\text { Quartz veins } \\
\text { associated } \\
\text { with shear } \\
\text { band }\end{array}$ & Crack-seal & -152.24506 & 58.38931 & 15 & 0.637 & 325.47 & 30.66 \\
\hline $\begin{array}{l}\text { Makimine } \\
\text { Group }\end{array}$ & 18NOB23B & $\begin{array}{c}\text { Quartz veins } \\
\text { associated } \\
\text { with lineated } \\
\text { quartz vein at } \\
\text { low-angle to } \\
\text { schistosity }\end{array}$ & Crack-seal & 131.87875 & 32.76136 & 32 & 0.65 & 338 & 10 \\
\hline 2019KO24A & $\begin{array}{c}\text { Tension crack } \\
\text { in chert lenses } \\
\text { associated } \\
\text { with shear } \\
\text { band }\end{array}$ & $\begin{array}{l}\text { CL-blue and } \mathrm{CL} \\
\text { brown growth } \\
\text { rims }\end{array}$ & -154.02900 & 57.65183 & 12 & 0.57 & 234 & 14 & \\
\hline
\end{tabular}

Echantillon pour Raman

19K037A

18NOB22A

19KO23D 


\begin{tabular}{|c|c|c|c|c|c|c|c|c|c|}
\hline $\begin{array}{l}\text { Coherent } \\
\text { Hyuga } \\
\text { Formation }\end{array}$ & 18NOB02E & $\begin{array}{c}\text { Tension crack } \\
\text { in sandstone } \\
\text { beds } \\
\text { associated } \\
\text { with shear } \\
\text { band }\end{array}$ & $\begin{array}{c}\text { CL-blue and CL } \\
\text { brown growth } \\
\text { rims }\end{array}$ & 131.29864 & 32.38600 & 11 & 0.56 & 207 & 25 \\
\hline
\end{tabular}

18NOB10G 


\begin{tabular}{|c|c|c|c|c|c|c|c|c|}
\hline Geological Unit & Sample & Longitude & Latitude & $\begin{array}{c}\text { RSCM: } \\
\text { number of } \\
\text { analyses }\end{array}$ & $\begin{array}{c}\mathrm{RA} 1=(\mathrm{D} 1+ \\
\mathrm{D} 4) / \\
(\mathrm{D} 1+\mathrm{D} 2+ \\
\mathrm{D} 3+\mathrm{D} 4+\mathrm{G})\end{array}$ & $\begin{array}{l}\text { Veining mean } \\
\text { temperature } \\
\left({ }^{\circ} \mathrm{C}\right)\end{array}$ & $\begin{array}{c}\text { Temperature } \\
\text { standard } \\
\text { deviation }\left({ }^{\circ} \mathrm{C}\right)\end{array}$ & $\begin{array}{l}\text { Average } \mathrm{T} \text { for } \\
\text { the unit }\left({ }^{\circ} \mathrm{C}\right)\end{array}$ \\
\hline \multirow{3}{*}{ Uyak Complex } & KO25E & 152.514747 & 58.43052 & 11 & 0.585 & 262 & 12 & \multirow{3}{*}{271} \\
\hline & KO25F & 152.514747 & 58.43052 & 10 & 0.588 & 273 & 6 & \\
\hline & KO27A & -152.536044 & 58.4095575 & 15 & 0.599 & 279 & 17 & \\
\hline \multirow{2}{*}{ Kodiak Landward Belt } & KO27B & -152.536044 & 58.4095575 & 15 & 0.602 & 283 & 7 & \multirow{2}{*}{289} \\
\hline & KO28 & -152.518329 & 58.407546 & 12 & 0.612 & 295 & 8 & \\
\hline \multirow{6}{*}{ Kodiak Central Belt } & KO33 & -152.256844 & 58.35756 & 15 & 0.644 & 333 & 19 & \multirow{6}{*}{330} \\
\hline & KO34 & -152.239673 & 58.3459462 & 15 & 0.64 & 328 & 13 & \\
\hline & KO36 & -152.258566 & 58.3661403 & 15 & 0.641 & 330 & 29 & \\
\hline & KO37 & -152.269629 & 58.3748567 & 15 & 0.637 & 325 & 31 & \\
\hline & KO38 & -152.286457 & 58.3889129 & 15 & 0.65 & 340 & 28 & \\
\hline & KO39 & -152.281502 & 58.3867695 & 17 & 0.636 & 324 & 12 & \\
\hline
\end{tabular}

This article is protected by copyright. All rights reserved. 


\begin{tabular}{|c|c|c|c|c|c|c|}
\hline Element & Li7 (ppm) & Al27 (ppm) & $\mathrm{Na} 23$ (ppm) & K39 (ppm) & $\begin{array}{c}\begin{array}{c}\text { Cathodoluminescenc } \\
\text { e color ( } 0=\text { brown. } \\
1=\text { blue) }\end{array} \\
\end{array}$ & $\begin{array}{l}\text { Fluid inclusion density } \\
\text { ( } 0=\text { zero. } 3=\text { very high) }\end{array}$ \\
\hline \multicolumn{7}{|l|}{ KODIAK } \\
\hline 2019-KO-24-4-zone4_26 & 1.067 & 29.05 & 33.47 & 8.75 & 0 & 0 \\
\hline 2019-KO-24-4-zone4_27 & 0.999 & 33.43 & 18.49 & 4.85 & 0 & 0 \\
\hline 2019-KO-24-4-zone4_28 & 0.358 & 18.3 & 24.11 & 5.47 & 0 & 0 \\
\hline 2019-KO-24-4-zone4_29 & 0.587 & 21.73 & 29.8 & 7.88 & 0 & 0 \\
\hline 2019-KO-24-4-zone4_30 & 9 & 217.54 & 39.33 & 6.4 & 0 & 0 \\
\hline 2019-KO-24-zone6_49 & 0.137 & 14.85 & 5.81 & 3.54 & 0 & 0 \\
\hline 2019-KO-24-zone6_50 & 1.672 & 41.66 & 4.62 & 0.51 & 0 & 0 \\
\hline 2019-KO-24-zone6_51 & 1.215 & 40.39 & 3.64 & & 0 & 0 \\
\hline 2019-KO-24-zone6_52 & 2.143 & 48.68 & 5.51 & - & 0 & 0 \\
\hline 2019-KO-24-zone6_53 & 0.39 & 16.65 & \begin{tabular}{l|l}
4.02 \\
\end{tabular} & 1.26 & 0 & 0 \\
\hline 2019-KO-24-zone6_54 & 1.059 & 29.8 & 10.64 & 1.7 & 0 & 0 \\
\hline 2019-KO-24-zone6_55 & 0.511 & 34.95 & 13.33 & 9.38 & 0 & 0 \\
\hline 2019-KO-24-zone6_56 & 3.143 & 102.06 & 20.53 & 15.03 & 0 & 0 \\
\hline 2019-KO-24-4-zone13_91 & 0.33 & 53 & 52.96 & 32.56 & 0 & 0 \\
\hline 2019-KO-24-4-zone13_92 & 0.851 & 40.21 & 44.76 & 17.2 & 0 & 0 \\
\hline 2019-KO-24-4-zone13_93 & 0.576 & 23.92 & 19.39 & 10.31 & 0 & 0 \\
\hline 2019-KO-24-4-zone13_94 & 2.401 & 56.64 & 9.76 & 3.59 & 0 & 0 \\
\hline 2019-KO-24-4-zone13_95 & 3.724 & 78.76 & 13.37 & 5.12 & 0 & 0 \\
\hline 2019-KO-24-4-zone13_96 & 1.267 & 30.23 & 11.51 & 2.89 & 0 & 0 \\
\hline 2019-KO-24-4-zone13_97 & 3.142 & 78.94 & 19 & 4.11 & 0 & 0 \\
\hline 2019-KO-24-4-zone13_98 & 0.582 & 17.21 & 18.35 & 6.55 & 0 & 0 \\
\hline 2019-KO-24-4-zone13_99 & 0.467 & 17.5 & 20.37 & 4.4 & 0 & 0 \\
\hline 2019-KO-24-4-zone13_100 & 0.726 & 21.11 & 2.46 & - & 0 & 0 \\
\hline 2019-KO-24-4-zone4_4 & 6.91 & 154.21 & 75.05 & 15.81 & 1 & 0 \\
\hline 2019-KO-24-4-zone4_5 & 7.56 & 180 & 6.97 & - & 1 & 0 \\
\hline 2019-KO-24-4-zone4_6 & 1.607 & \begin{tabular}{l|l}
49.19 \\
\end{tabular} & 19.98 & - & 1 & 0 \\
\hline 2019-KO-24-4-zone4_7 & 0.477 & 23.55 & 4.34 & - & 1 & 0 \\
\hline 2019-KO-24-4-zone4_8 & 0.839 & 29.15 & 9.01 & - & 1 & 0 \\
\hline 2019-KO-24-4-zone4_9 & 5.04 & 119.27 & 5.95 & - & 1 & 0 \\
\hline 2019-KO-24-4-zone4_10 & 5.1 & 128.43 & 9.46 & 4.45 & 1 & 0 \\
\hline 2019-KO-24-4-zone4_11 & 5.98 & 151.78 & 6.56 & & 1 & 0 \\
\hline 2019-KO-24-4-zone4_12 & 4.67 & 117.74 & 13.75 & 1.82 & 1 & 0 \\
\hline 2019-KO-24-4-zone4_13 & 9.95 & 226.28 & 4.73 & - & 1 & 0 \\
\hline 2019-KO-24-4-zone4_14 & 10.84 & 287.38 & 8.33 & 9.98 & 1 & 0 \\
\hline 2019-KO-24-4-zone4_15 & 12.11 & 382.91 & 21.85 & 42.08 & 1 & 0 \\
\hline 2019-KO-24-4-zone4_18 & 16.13 & 376.02 & 26.04 & 10.48 & 1 & 0 \\
\hline 2019-KO-24-4-zone4_19 & 11.51 & 288.43 & 7.09 & 0.92 & 1 & 0 \\
\hline 2019-KO-24-4-zone4_20 & 11.43 & 289.53 & 22.04 & 9.14 & 1 & 0 \\
\hline 2019-KO-24-4-zone4_21 & 1.599 & 47.81 & 7.29 & 4.52 & 1 & 0 \\
\hline 2019-KO-24-zone6_37 & 17.45 & 445.34 & 5.53 & & 1 & 0 \\
\hline 2019-KO-24-zone6_38 & 14.63 & 366.27 & 5.73 & - & 1 & 0 \\
\hline 2019-KO-24-zone6_39 & 17.13 & 409.75 & 11.52 & - & 1 & 0 \\
\hline 2019-KO-24-zone6_40 & 6.855 & 160.01 & 6.7 & - & 1 & 0 \\
\hline 2019-KO-24-zone6_41 & 3.347 & 96.29 & 8.09 & - & 1 & 0 \\
\hline 2019-KO-24-zone6_57 & 4.005 & 111.03 & 17.41 & 9.28 & 1 & 0 \\
\hline 2019-KO-24-4-zone13_77 & 10.545 & 266.69 & 16.86 & 4.72 & 1 & 0 \\
\hline 2019-KO-24-4-zone13_78 & 12.73 & 394.68 & 20.01 & 16.73 & 1 & 0 \\
\hline 2019-KO-24-4-zone13_79 & 12.03 & 298.02 & 11.45 & 7.99 & 1 & 0 \\
\hline 2019-KO-24-4-zone13_80 & 7.497 & 184.09 & 5.36 & 2.33 & 1 & 0 \\
\hline 2019-KO-24-4-zone13_81 & 9.04 & 243.37 & 16.24 & 10.88 & 1 & 0 \\
\hline 2019-KO-24-4-zone13_82 & 5.572 & 128.21 & 9.1 & 2.75 & 1 & 0 \\
\hline 2019-KO-24-4-zone13_83 & 5.209 & 128.07 & 3.19 & & 1 & 0 \\
\hline 2019-KO-24-4-zone13_84 & 2.225 & 65.85 & 6.46 & 1.54 & 1 & 0 \\
\hline 2019-KO-24-4-zone13_85 & 1.351 & 36.93 & 6.74 & 2.97 & 1 & 0 \\
\hline 2019-KO-24-4-zone13_86 & 1.464 & 37.91 & 4.99 & - & 1 & 0 \\
\hline 2019-KO-24-4-zone13_87 & 0.703 & 25.32 & 4.19 & 0.8 & 1 & 0 \\
\hline
\end{tabular}

This article is protected by copyright. All rights reserved. 


\begin{tabular}{|c|c|c|c|c|c|c|}
\hline 2019-KO-24-4-zone13_88 & 1.082 & 32.71 & 16.15 & 1.28 & 1 & 0 \\
\hline 2019-KO-24-zone6_42 & 1.161 & 229.82 & 11.19 & 66.9 & 1 & 1 \\
\hline 2019-KO-24-zone6_43 & 0.43 & 29.32 & 6.03 & 4.61 & 1 & 1 \\
\hline 2019-KO-24-zone6_44 & 0.564 & 228.9 & 19.45 & 52.78 & 1 & 1 \\
\hline 2019-KO-24-zone6_45 & 0.092 & 23.33 & 10.69 & 5.57 & 1 & 1 \\
\hline \multicolumn{7}{|c|}{ Helminthoides Flysch } \\
\hline FH119-zoneC-115 & 0.722 & 14.16 & 4.57 & - & 0 & 0 \\
\hline FH119-zoneC-116 & 1.92 & 29.4 & 3.1 & - & 0 & 0 \\
\hline FH119-zoneC-117 & 1.244 & 25.36 & 15.35 & - & 0 & 0 \\
\hline FH119-zoneC-118 & & 1.938 & 6.94 & - & 0 & 0 \\
\hline FH119-zoneC-119 & & 1.275 & 4.57 & - & 0 & 0 \\
\hline FH119-zoneC-120 & & 3.85 & 21.62 & - & 0 & 0 \\
\hline FH119-zoneC-121 & - & 1.317 & 2.72 & 0.798 & 0 & 0 \\
\hline FH4_ZoneD2_46 & - & 41.56 & 7.87 & - & 0 & 1 \\
\hline FH4_ZoneD2_47 & 1.209 & 30.53 & 6.6 & - & 0 & 1 \\
\hline FH4_ZoneD2_48 & 0.774 & 22.74 & 10.67 & - & 0 & 1 \\
\hline FH4_ZoneD2_49 & 2.025 & 36.88 & 16.56 & - & 0 & 1 \\
\hline FH4_ZoneD2_50 & 0.315 & 16.55 & 17.99 & - & 0 & 1 \\
\hline FH4_ZoneD2_51 & 3.62 & \begin{tabular}{l|l|}
44.9 \\
\end{tabular} & 51.91 & - & 0 & 1 \\
\hline FH13-4-zone3-53 & 2.106 & 47.32 & 18.17 & 0.351 & 0 & 1 \\
\hline FH13-4-zone3-54 & 0.433 & 14.02 & 3.49 & - & 0 & 1 \\
\hline FH13-4-zone3-55 & 2.226 & 37.67 & 4.85 & - & 0 & 1 \\
\hline FH13-4-zone3-56 & 0.461 & 21.32 & 32.31 & 0.296 & 0 & 1 \\
\hline FH13-4-zone3-57 & 9.56 & 99.74 & 19.25 & - & 0 & 1 \\
\hline FH13-4-zone3-58 & 11.41 & 149.8 & 5.55 & - & 0 & 1 \\
\hline FH119-zoneC-110 & 1.687 & 30.59 & 4.42 & 0.65 & 1 & 0 \\
\hline FH119-zoneC-111 & 2.101 & 32.27 & 3.12 & & 1 & 0 \\
\hline FH119-zoneC-112 & 2.064 & 31.62 & 2.19 & 0.313 & 1 & 0 \\
\hline FH119-zoneC-113 & 3.066 & 45.33 & 14.14 & - & 1 & 0 \\
\hline FH119-zoneC-114 & 0.951 & 17.85 & 13.13 & - & 1 & 0 \\
\hline FH119-zoneC-125 & 2.991 & 53.31 & 34.44 & 1.72 & 1 & 1 \\
\hline FH119-zoneC-126 & 2.522 & 43.93 & 16.33 & - & 1 & 1 \\
\hline FH119-zoneC-127 & 1.445 & 32.8 & 17.67 & - & 1 & 1 \\
\hline FH119-zoneC-128 & 2.046 & 33.44 & 5.79 & - & 1 & 1 \\
\hline FH119-zoneC-129 & 3.32 & 52.03 & 9.01 & - & 1 & 1 \\
\hline FH119-zoneC-130 & 2.597 & 45.3 & 13.91 & - & 1 & 1 \\
\hline FH119-zoneC-131 & 0.701 & 15.9 & 4.72 & - & 1 & 1 \\
\hline FH13-4-zone3-19 & 40.08 & 480.34 & 5.32 & 0.248 & 1 & 1 \\
\hline FH13-4-zone3-21 & 37.46 & 459.42 & 626.49 & 11.66 & 1 & 1 \\
\hline FH13-4-zone3-22 & 32.55 & 411.35 & 210 & 4.27 & 1 & 1 \\
\hline FH13-4-zone3-23 & 27.85 & 360.79 & 64.06 & 1.38 & 1 & 1 \\
\hline FH13-4-zone3-24 & 38.02 & 481.92 & 80.33 & 1.94 & 1 & 1 \\
\hline FH13-4-zone3-25 & 48.41 & 564.67 & 43.64 & 0.731 & 1 & 1 \\
\hline FH13-4-zone3-26 & 42.24 & 535.73 & 28.07 & 1.281 & 1 & 1 \\
\hline FH13-4-zone3-27 & 34.44 & 451.42 & 14.19 & - & 1 & 1 \\
\hline FH13-4-zone3-28 & 16.8 & 209.5 & 49.02 & 0.739 & 1 & 1 \\
\hline FH13-4-zone3-29 & 14.31 & 185.63 & 39.61 & 0.8 & 1 & 1 \\
\hline FH13-4-zone3-34 & 34.93 & 449.59 & 17.76 & 0.498 & 1 & 1 \\
\hline FH13-4-zone3-35 & 26.49 & 335.8 & 13.16 & - & 1 & 1 \\
\hline FH13-4-zone3-36 & 39.34 & 525.62 & 19.83 & - & 1 & 1 \\
\hline FH13-4-zone3-37 & 27.79 & 373.53 & 10.53 & - & 1 & 1 \\
\hline FH13-4-zone3-38 & 21.55 & 288.47 & 13.43 & -1 & 1 & 1 \\
\hline FH13-4-zone3-39 & 20.02 & 287.63 & 9.89 & 0.546 & 1 & 1 \\
\hline FH13-4-zone3-59 & 21.45 & 334.76 & 3.26 & - & 1 & 1 \\
\hline FH13-4-zone3-60 & 18.86 & 266.97 & 17.11 & - & 1 & 1 \\
\hline FH13-4-zone3-61 & 14.61 & 225.84 & 40.64 & 1.22 & 1 & 1 \\
\hline FH13-4-zone3-62 & 23.83 & 343.29 & 67.76 & 0.628 & 1 & 1 \\
\hline FH13-4-zone3-63 & 15.67 & 236.4 & 36.95 & 1.52 & 1 & 1 \\
\hline FH13-4-zone3-64 & 17.12 & 267.05 & 21.48 & 0.351 & 1 & 1 \\
\hline
\end{tabular}

This article is protected by copyright. All rights reserved. 


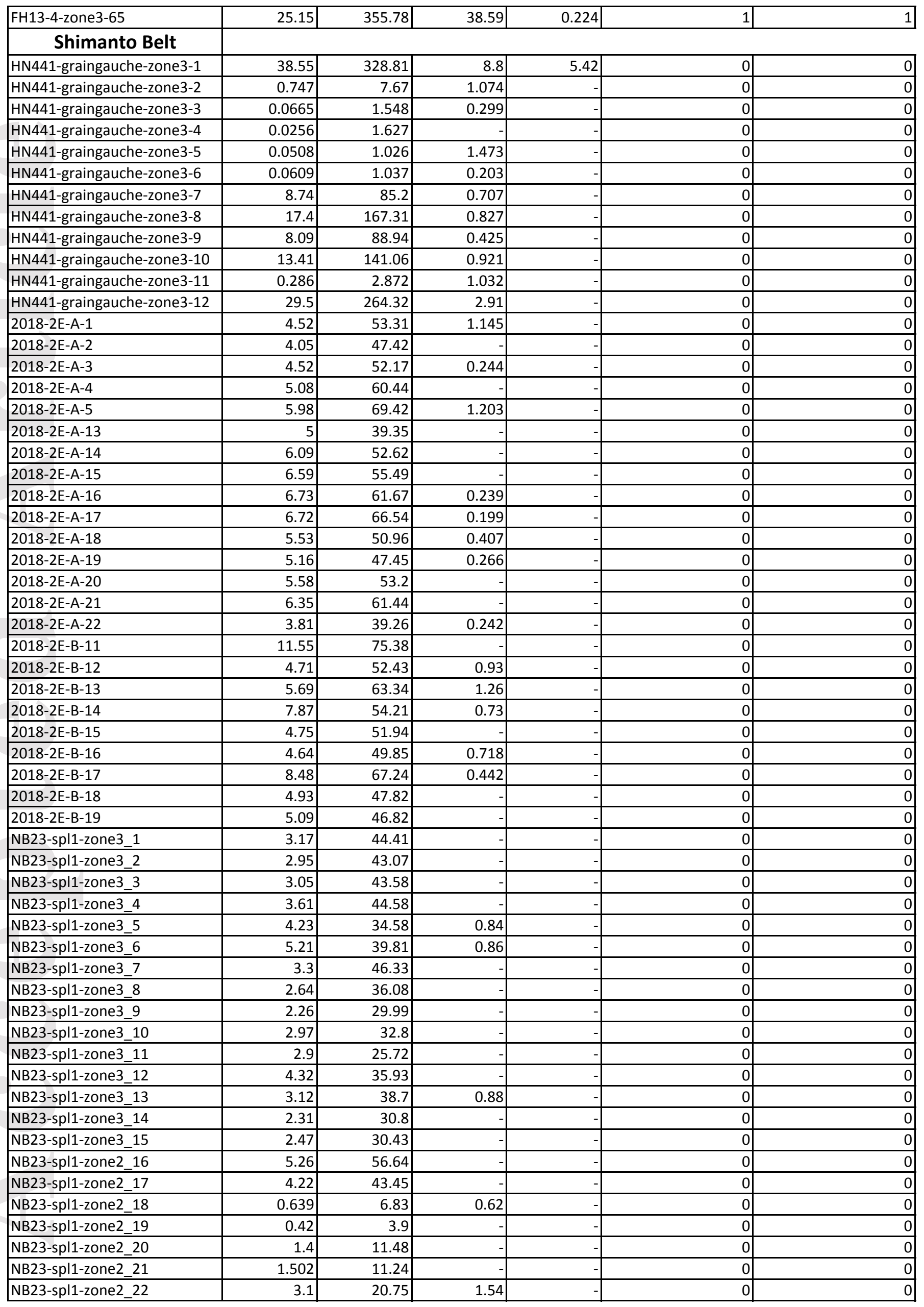

This article is protected by copyright. All rights reserved. 


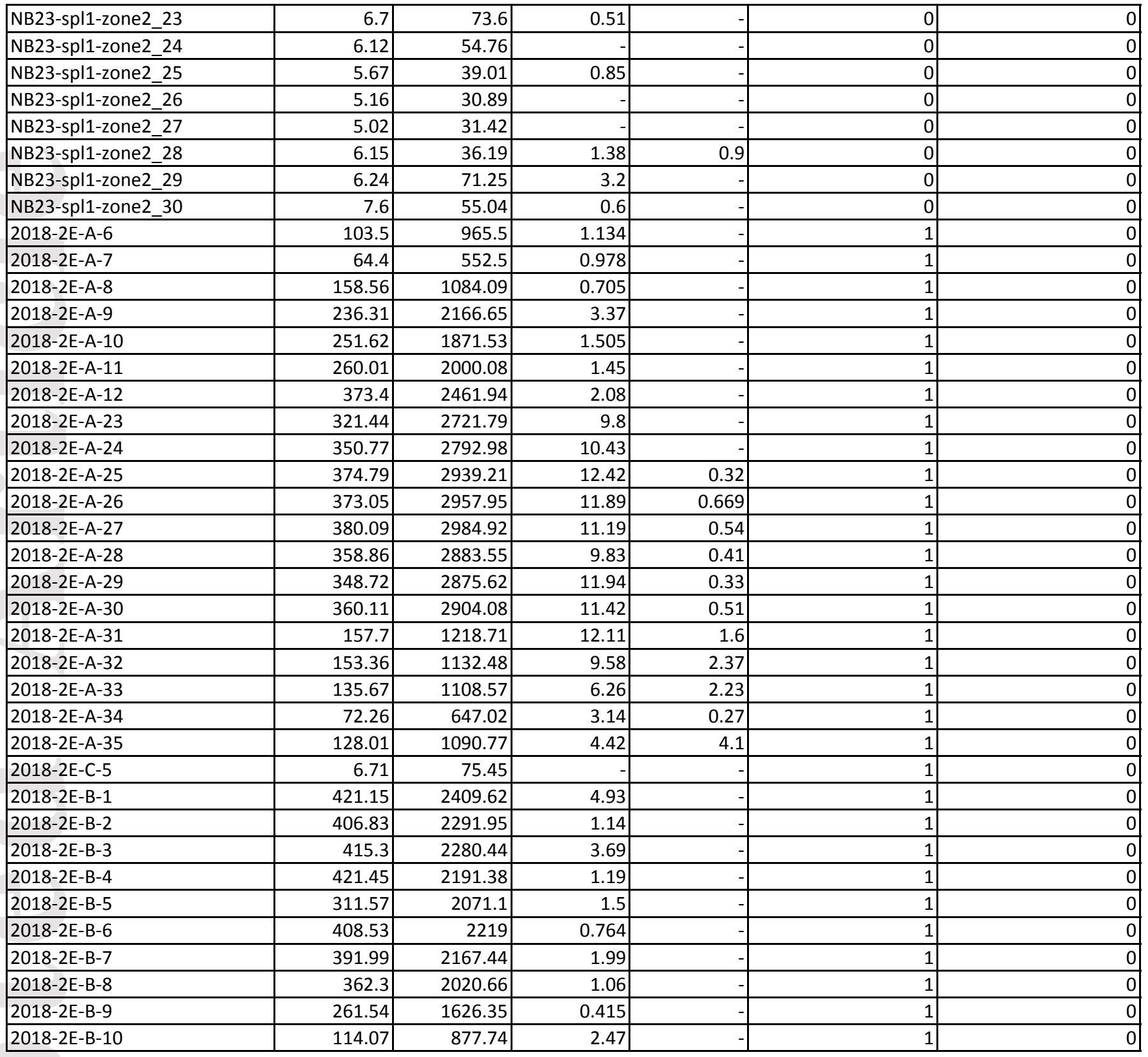

This article is protected by copyright. All rights reserved. 